\title{
Short and Long Recall Errors in Retrospective Household Surveys: Evidence from a Developing Country
}

\author{
September 2018
}

\begin{abstract}
While recall errors in retrospective data from household surveys may generate estimation biases, the nature and the relative magnitude of the errors are still largely unknown, especially in the context of developing countries. To bridge this gap in the existing studies, we conduct a resurvey of respondents of the Vietnam Household Living Standards Survey (VHLSS) 2006. The combined data set allows us to investigate a variety of short-term and long-term errors associated with recall surveys. First, our empirical results suggest that when we ask total expenditure rather than categorized expenditures, long recall errors are no worse than short recall errors. Second, we found mean-reversion only for long recall errors in the sum of categorized expenditures but not necessarily for total expenditure. Finally, the inclusion of household size, asset, income, and geographical dummy variables in regression analyses may mitigate the biases arising from measurement errors.
\end{abstract}

Keywords: Consumption; Income; Household Survey; Non-classical Measurement Errors; Recall Errors

JEL Classification Numbers: D12, O12 
Consumption and income are the two most commonly used variables to measure welfare, poverty, and wellbeing of individuals and/or households as well as to measure inequality across individuals or households. To collect these key data, household surveys are widely conducted in both developed and developing countries. Due to costs and administrative factors, however, smaller scale resurveys that include retrospective questions on consumption and income are often used to construct panel data so as to add observations of these variables to existing cross-sectional household surveys (Deaton and Grosh, 2000). Retrospective questions are also useful in evaluating natural experiments ex post - for instance, impacts of natural disasters and policy changes in the past. Note also that any recall data may suffer from measurement errors, which are not directly verifiable, since the true values are not directly observable. This paper therefore studies the nature and relative magnitude of short-term and long-term recall errors in retrospective data from household surveys, which are still largely unknown in the existing literature.

When consumption and income enter as independent variables in a regression model, attenuation bias arising from measurement errors in retrospective data may cause problems. Specifically, when a variable with errors is used as the dependent variable in a regression model, the errors will cause an estimation bias, when the errors are correlated with independent variables or involve a mean-reverting pattern (Gibson and Kim, 2007, 2010). This study adds evidence to the literature on consumption recall errors that has started to gain more attention (Battistin, Miniaci and Weber (2003), Ahmed, Brzozowski and Crossley (2006), Attanasio, Battistin, and Ichimura (2007), Attanasio and Pistaferri (2016), and Crossley and Winter (2015) for data from developed countries). In the context of developing countries, notable studies include Chesher and Schluter (2002), Gibson 
(2002), Gibson and Kim (2007, 2010), Brozozowski, Crossley, and Winter (2017), and Conforti, Grünberger and Troubat (2017). Some of these existing studies show that recall errors are not necessarily random: first, measurement errors in consumption data are often correlated with observed household characteristics such as household size (Gibson, 2002; Gibson and Kim, 2007); second, the errors generate non-classical measurement errors that cannot be mitigated by standard instrumental variable methods (Black, Berger and Scott, 2000; Gibson and Kim, 2007, 2010; Brozozowski, Crossley, and Winter 2017); and third, the errors exhibit a mean-reverting pattern especially for food consumption and for rural households (Gibson et al., 2015).

However, the nature and the causes of recall errors are still largely unknown for data collected in developing countries, and biases arising from these errors have largely been ignored in most existing studies. In particular, there is hardly any consensus about the best ways to design expenditure modules that would minimize the problems arising from recall biases. Reporting total expenditures by rules of sum may be difficult for many households, while reporting expenditures on each category of consumption might be hard for some households - for instance, very wealthy or large households consuming an extremely large number and range of items or goods.

To fill the gap, we collect a unique household data set from Vietnam by conducting a resurvey of the respondents of the Vietnam Household and Living Standards Survey (VHLSS) 2006. This data set, together with the VHLSS 2006 dataset, allows us to investigate a variety of short-term and long-term errors in retrospective surveys - both those asking total expenditures and those asking category-wise expenditures. In this paper, we aim to identify the systematic features of retrospective surveys, enabling us to make 
amendments when we conduct regression analyses.

To preview, four findings emerge from our analyses. First, there is a systematic bias arising from aggregation of categorized expenditures when we use long recall data. In contrast, long recall errors are no worse than short recall errors when we ask total expenditure. Second, measurement errors are more serious in consumption of selfgenerated goods than they are in bought/bartered consumption expenditures. Third, measurement errors in retrospective expenditures data seem to be systematically correlated with asset, income, household size, and province dummies. This suggests that the inclusion of these variables as control variables in regressions may mitigate biases arising from measurement errors. Finally, as Gibson and Kim (2007, 2010) found, we find limited evidence suggesting that long recall errors in the sum of categorized expenditures tend to exhibit mean-reverting patterns. Thus, the use of expenditures data with this meanreverting error as a dependent variable would generate a downward bias in the estimated coefficient, in contrast to the attenuation bias arising from classical measurement errors in independent variables.

The remainder of this paper is organized as follows. The next presents the conceptual framework for our analysis on retrospective survey errors. Then we describe our data, and report the empirical results. The last section concludes the paper.

\section{The Conceptual Framework}

In this section, we summarize the conceptual framework for analysing consumption data collected in a retrospective survey. When we use retrospective data as independent 
variables, attenuation biases arising from classical measurement errors should be handled carefully. The instrumental variable approach is the standard method for dealing with this problem. Even when using a retrospective consumption variable as a dependent variable, serious bias may arise. To illustrate this problem, we consider two cases. First, suppose we are interested in estimating the following regression model:

$$
y=X \beta+u,
$$

where $y$ is consumption without retrospective survey errors, $X$ is a set of independent variables determining consumption and $u$ is a mean-zero error term, and that, we assume $E(u \mid X)=0$. For example, for an estimation of a consumption equation based on the lifecycle permanent income hypotheses, $X$ should include a variety of household characteristics and assets, representing each household's levels of physical, financial, and human assets.

Let $y^{S}$ denote the dependent variable collected through a short recall survey. Note that $y^{S}=y+v^{S}$, where $v^{S}$ represents errors arising from the short recall survey. Accordingly, the model we can estimate with observable data is:

$$
y^{S}=X \beta+v^{S}+u
$$

Since it is likely that the retrospective errors are systematically related to household 
characteristics, we have $E\left(v^{S} \mid X\right) \neq 0 .{ }^{1}$

Suppose that there is another set of retrospective survey data that have a longer time lag than the short recall survey, i.e., a long recall survey, and let $y^{L}$ denote a long recall variable:

$$
y^{L}=X \beta+v^{L}+u .
$$

where $v^{L}$ represents errors arising from a long recall survey. Just like above, we have $E\left(v^{L} \mid X\right) \neq 0$.

When long and short recall data are available simultaneously, we may empirically investigate the conditional expectation of $v^{L}-v^{S}$, i.e., $E\left(v^{L}-v^{S} \mid X\right)$, because $v^{L}-v^{S}=y^{L}-$ $y^{S}$, and the difference $y^{L}-y^{S}$ is observable. ${ }^{2}$ If $E\left(v^{L}-v^{S} \mid X\right)=0$, then the nature of the measurement error of the recall data is stable. Note that $E\left(v^{S} \mid X\right)=E\left(v^{L} \mid X\right)=0$ implies $E\left(v^{L}\right.$ $\left.-v^{S} \mid X\right)=0$. By transposition, if $E\left(v^{L}-v^{S} \mid X\right) \neq 0$, then the condition that $E\left(v^{S} \mid X\right)=E\left(v^{L} \mid X\right)$ $=0$ does not hold; thus, at least one of the recall errors generates an endogeneity bias. It follows that we can test the existence of an endogeneity bias by testing the null hypothesis, $E\left(v^{L}-v^{S} \mid X\right)=0$. Moreover, when the null hypothesis $E\left(v^{L}-v^{S} \mid X\right)=0$ is not rejected, we are unable to say anything regarding $E\left(v^{S} \mid X\right)=0$ or $E\left(\nu^{L} \mid X\right)=0$. Nevertheless, the nonrejection of the null hypothesis indicates that the use of long recall data would be no worse than the use of short recall data as far as endogeneity bias is concerned.

$1 X$ in practice would also be recall data; thus, it may suffer from classical measurement errors, too.

${ }^{2}$ In practice, survey questions that correspond to $y^{L}$ and $y^{S}$ may not be identical. Thus, phrasing issues could potentially introduce confounding factors. 
In empirical analyses, we adopt two alternative assumptions. First, we assume that the conditional expectation of $v^{L}-v^{S}$ given $X$ is linear in $X$. Then, we test the null hypothesis such that the coefficients of the linear conditional expectation function of $v^{L}-$ $v^{S}$ are jointly zero. Second, we also employ the median regression function of $v^{L}-v^{S}$ conditional on $X$, i.e., $Q_{1 / 2}\left(v^{L}-v^{S} \mid X\right)$, where the conditional median function is taken to be linear in $X$. By the median regression model, we aim to mitigate the problem arising from the outliers.

Second, another measurement error problem arises when the measurement error is mean reverting (Gibson and Kim, 2007; Gibson and Kim, 2010). Following Gibson and Kim (2010), suppose that the observed dependent variable is represented by

$$
y^{L}-y^{S}=\theta+(\lambda-1) y^{S}+\xi,
$$

where a mean reverting error arises when $\lambda<1$ holds. In this case, as shown by Gibson and Kim (2010), estimated regression coefficients are downward biased. We estimate equation (4) by regressing the gap between the long and short recall data on short recall data. Since $y^{S}$ may well include measurement errors, the estimated coefficient $(\lambda-1)$ may involve an attenuation bias. Hence, when the coefficient attached to the short recall variable $y^{S}$ turns out to be strictly negative, it is safe to say that the result is consistent with the meanreverting measurement error.

We should note that equations (2) and (4) together give the same form as equation (3). This suggests that equation (4) is a structural equation and equation (3) is a reduced form equation. If $\lambda<1$ holds in equation (4), an OLS estimate of equation (3) gives an 
unbiased estimator of $\lambda \beta$, leading to a downward bias of $\beta$. In this way, equations (3) and (4) are related. However, equation (3) can accommodate model forms other than the structural equations of (2) and (4). Hence, equation (3) can be viewed as a more general model than equation (4).

\section{Data: Sampling Strategies and Description}

We use a unique panel data set from Vietnam, which is a combination of two data sets; the Vietnam Household Living Standards Survey (VHLSS) 2006 data and a unique survey data

set collected jointly by the Research Institute of Economy, Trade and Industry (RIETI) and the Center for Agricultural Policy in Vietnam (CAP). We refer to the latter data set as RIETI-CAP data.

VHLSS is a biennial, nationally representative, rotating-panel household survey conducted by Vietnam's General Statistics Office (GSO) with technical assistance from the UNDP and the World Bank. VHLSS is a multi-purpose household survey covering a variety of topics such as household characteristics, expenditures, income, health, and education. Enumeration areas of the VHLSS data are chosen randomly from the 1999 Population Census enumeration areas, and households are selected randomly in each enumeration area. In VHLSS 2006, 36,000 households were surveyed to provide representative income and other statistics at the provincial level. However, the sample size of the expenditure module was reduced to a quarter of the income survey, enabling comparisons between major groups of households and individuals, but not comparisons at the provincial level.

The RIETI-CAP survey is a resurvey of subsamples of the VHLSS 2006 
respondents in four selected provinces: Ha Tay, Nghe An, Quang Nam, and Lao Cai Provinces. ${ }^{3}$ The RIETI-CAP survey was conducted from late February 2008 until early April 2008, and includes all households included in VHLSS 2006 for the four provinces, i.e. households both with and without the expenditure module. The data covers around 500 households from each province, where 100 households are with both income and expenditures data and 400 households are with income data only. Accordingly, we collected data from a total of 2,018 households. The data include a variety of information such as current and retrospective income and expenditures information, asset information, subjective questions on insurance subscriptions, borrowing, past loss experiences of natural disasters, risk attitude, willingness-to-pay for various hypothetical insurance schemes, and time preference.

\section{Consumption Module}

In this subsection, we describe data on consumption expenditures in the VHLSS 2006 and RIETI survey data sets. In VHLSS 2006, detailed information was sought on market purchases and consumption of self-generated goods for 57 daily food and drink items, 21 daily non-food items (such as lottery tickets, cigarettes, soap, personal care products,

3 Since the RIETI-CAP survey aims at collecting data to help design an insurance scheme that covers avian influenza and other natural disasters (flooding), sub-samples of VHLSS 2006 are chosen from four different provinces that were (1) only hit by avian influenza (Ha Tay province); (2) only hit by natural disasters (Nghe An Province); (3) hit by both avian influenza and natural disasters (Quang Nam Province); and (4) neither hit by avian influenza nor by natural disasters (Lao Cai Province). The selection of these four provinces was made using commune-level data in VHLSS 2004 (Nakata, Sawada, and Tanaka, 2010). Appendix A shows the locations of these provinces. 
cooking fuel, matches and candles, and gasoline), and 33 annual non-food items (such as fabrics, ready-made clothing, mosquito nets, face towels, scarves, rush mats, blankets, pillows, tailoring or laundry services, shoes, nylon sheeting, light buds, and electric wire). For daily food items, VHLSS 2006 collected the number of months in the past 12 months, in which purchases were made for each food item; the average number of times of purchases made in a month for these months; the average quantity per purchase, and the monetary value per purchase. These pieces of information can be combined to obtain the aggregate expenditures in the last 12 months to the interview day. Besides market purchases including the bartered amount, information on consumption of self-generated goods was also collected. Note that the data are collected separately for during holidays and for other periods.

Consumption questions in the RIETI-CAP Survey essentially follow VHLSS 2006, although the consumption items specified are restricted to 12 food and non-food items. Thus, in addition to asking the market purchases and/or the consumption of self-generated goods for the 12 items, the survey asks the total monetary values of consumption items bought/bartered, and self-generated or given. We call the sum of expenditures on the 12 food and non-food items the "sum of categorized expenditures," and the total monetary values of consumption items "total expenditure," both for bought/bartered goods and selfgenerated goods. Thus, we generate two distinct aggregate expenditures variables for both bought/bartered goods and self-generated goods from the RIETI-CAP data, unlike from the VHLSS 2006, where there is only one for both bought/bartered goods and self-generated goods. See Appendix B for the actual expenditure module used in the RIETI-CAP questionnaire. The survey also asked about the rate of change for the total monetary values 
of consumption from the year before. ${ }^{4}$ Hence, the RIETI-CAP survey provides us with long recall information of 24 months. These consumption categories and rates of changes are carefully set so that the RIETI-CAP and VHLSS 2006 data can be matched and compared. ${ }^{5}$ Since the VHLSS 2006 data set is based on 12-month short recall, we call this data "short recall" as opposed to the RIETI-CAP survey, which gives 24-month long recall data. We call the latter data "long recall."

\section{Empirical Results}

In our empirical implementation, we conduct five sets of analyses. First, we compare a variety of cumulative density functions (CDFs) to check the consistencies between the short recall (VHLSS 2006) and the long recall (RIETI-CAP) consumption data. Second, we examine the relative size of intensive and extensive margins of the gaps in short and long recall data. Third, following equations (2) and (3), we explore the relationship between the long and short recall error gap, i.e., $v^{L}-v^{S}$, and a set of observables $X$. Fourth, based on equation (4), we examine the mean-reverting nature of measurement errors by regressing the gap between the long-recall consumption variable from the RIETI-CAP data

\footnotetext{
4 We ask annual percent change ranges in total bought/bartered expenditures and in total selfgenerated or given consumption values between 2006 and 2007. Each range is represented by a particular number; medians for all ranges except for the two extreme ranges, i.e., $60 \%$ decrease for any decreases larger than $50 \%$, and $60 \%$ increase for any increases larger than $50 \%$. Even if we change values for the two extreme ranges to $75 \%$ changes, all the qualitative results remain unchanged.

${ }^{5}$ Data collection period of VHLSS 2006 was in May, June, and September 2006 while RIETI-CAP survey was done from February until April 2008. Hence, there are some timing issues in data collection. However, both total expenditure and the sum of categorized expenditures are affected in the same way due to this timing issue. So, it does not necessarily favor one over the other.
} 
and the short-recall consumption variable from VHLSS 2006 on the short recall consumption variable from VHLSS 2006. Finally, we explore the internal consistency of the RIETI-CAP data by comparing the CDFs of total expenditure and the sum of categorized expenditures in 2007 , both for bought/bartered and for self-generated goods.

\section{Comparisons of Consumption CDFs}

For comparisons of consumption CDFs, we obtain the following two sets of results. First, we compare the short-recall aggregate expenditures (VHLSS 2006 data) and the long-recall total expenditure (RIETI-CAP). The latter is based on total expenditure data in 2007 and the rates of changes in total expenditure. Figures 2 (a) and (b) represent the bought/bartered and self-generated goods, respectively. As we can see, there is a consistent gap between the two datasets. In fact, the long recall data tend to overestimate the short recall expenditure amounts, for both bought/bartered and self-generated goods.

Second, we compare the CDFs of the aggregate expenditures in 2006 based on the VHLSS 2006 data and the sum of categorized expenditures based on the RIETI-CAP survey. Figure 3 (a) and (b) represent bought/bartered goods and self-generated goods, respectively. As before, there is a consistent gap between the two datasets. We may conclude that irrespective of whether the questionnaire asks about total or categorized expenditures, the long recall data tend to overestimate the short recall expenditures amounts for both bought/bartered and self-generated goods.

While the above comparisons of the CDFs directly imply that the means of the long and short recall expenditures data are different, they provide no information about 
variance. We therefore conduct variance ratio tests between the long and short recall data. The variance ratio is 3.62 between the long-recall total expenditure and short-recall aggregate expenditures data on bought/bartered goods, 5.02 between those on selfgenerated goods, 3.38 between the long-recall sum of categorized expenditures and shortrecall aggregate expenditures data on bought/bartered goods, and 6.19 between those on self-generated goods. Thus, the null hypothesis that the variances of long and short recall data are the same is rejected in all cases; long recall data have a larger variance.

In the above comparisons of expenditures series, the two-sample KolmogorovSmirnov tests for equality of distribution functions reject the same CDFs of each pair CDF at 1 per cent level. We should note, however, that these consistent gaps do not necessarily imply estimation biases even if we employ the long recall data. This is simply because the gaps may be effectively captured by observable data and/or various fixed effects in estimation.

Intensive and extensive margin

We next compare the magnitude of short and long recall errors between the total expenditure data and the sum of categorized expenditures data. In addition to providing basic features of the data, we examine the relative magnitudes of the intensive and extensive margins of measurement errors. By following Friedman et al. (2017), which decomposes measurement errors into the intensive and extensive margins, we define the intensive margin of errors as the errors that arise from misreporting of expenditure values for those reporting a positive amount, and the extensive margin as the errors that originate 
from completely forgetting about consumption of an item and reporting zero consumption of it. Based on these definitions, the total expenditure data should not contain extensive margin errors since every household usually reports a positive amount of total expenditure, while the data may suffer from intensive margin of errors. In contrast, the sum of categorical expenditures data may suffer from the extensive margin errors arising from non-reporting of consumption in some of the items, but the intensive margin errors could be smaller because the intensive margin errors may cancel out through aggregation over several items when the errors tend to be random across items. It follows that comparing the magnitude of errors between total expenditure data and the sum of categorized expenditures data would indicate the relative magnitudes of intensive and extensive margins of the errors.

For the bought and bartered goods, the mean of the gap between long recall (from RIETI-CAP data) and short-recall (from VHLSS 2006) is 3701 thousand VND in the total expenditure data and 2469 thousand VND in the sum of categorized expenditures data. In comparison to the mean of short recall expenditures, this gap is $55 \%$ of the mean of short recall $($ mean $=6788)$ for the total expenditure data and $43 \%$ for the sum of categorical expenditure $($ mean $=5793)$. A similar pattern arises for the self-generated goods: the mean of the gap of the total expenditure data is $78 \%$ of the total short recall expenditure (mean gap $=2097$ and mean short recall expenditure $=2684)$ and the gap of the sum of categorical expenditures is $57 \%$ of the corresponding short recall expenditures (mean gap $=1516$ and mean short recall expenditures $=2656$ ). A possible interpretation of the results is that the intensive margin of recall errors, which arises from misreporting of values, dominates the the extensive margin, which comes from completely forgetting about the consumption per se. 


\section{Regression of the Consumption Gap on Household Characteristics}

To analyse the features of measurement errors in the retrospective survey, we employ equations (2) and (3) and regress the gap between long and short recall errors $v^{L}-v^{S}$ (or equivalently $y^{L}-y^{S}$, which is observable) on a set of observables $X$. We employ three sets of observables for the independent variable $X$ in equation (2) and (3): first, the characteristics of households and household heads; second, geographic variables; and third, the conditions of actual interviews. More specifically, we use the following variables. For the characteristics of households and household heads, we employ asset in 2007, total income in 2007, increase in income from 2006 to 2007, number of household members, and occupation of the household head, and the Kinh ethnicity dummy. Geographic variables include a dummy variable for rural areas and dummy variables for Ha Tay, Lao Cai, and Nghe An provinces. For variables that describe the actual interview conditions, we include a female respondent dummy, translator requirement dummy, and respondent characteristics captured by household member type, literacy, and age.

First, we examine the gap between the long-recall total expenditure variable based on the RIETI-CAP data and the short-recall aggregate expenditures variable based on the VHLSS 2006 data. As before, we investigated the gaps for bought/bartered expenditures (Table 1) and for self-generated goods (Table 2) separately. In Table 1, some province dummy variables have statistically significant coefficients. However, almost no other variables are consistently significant, suggesting that there exists little bias specific to longrecall total expenditure data for bought/bartered items. If we set a 5 percent significance 
level for the F-tests, seven out of eight specifications do not reject the null hypothesis of jointly zero coefficients. Moreover, the exclusion of province dummy variables provides us with the joint insignificance of other independent variables. This suggests that $v^{L}-v^{S}$ is not necessarily correlated with the observed household characteristics when we use total expenditure for bought/bartered items. ${ }^{6}$ Hence, no systematic bias that is unique to long recall data would emerge in comparison with short recall data as long as we use total expenditure for bought/bartered items.

The results for self-generated goods reported in Table 2, both OLS and median regressions, show that initial asset variables have statistically significant negative coefficients. This indicates that households with a larger asset holding tend to report a smaller long-short recall gap. Intriguingly, the current income variable has significantly positive coefficients. Unlike bought/bartered consumption, the joint $F$ test results indicate that the retrospective errors are correlated with the observables. Once we exclude asset, current income, and province dummy variables, other independent variables become jointly insignificant in five out of eight specifications.

Second, we compare the gap between the long-recall sum of categorized expenditures variable from the RIETI-CAP data and the short-recall aggregate expenditures variable from the VHLSS 2006 data. Again, we show the results separately, one for bought/bartered goods and the other for self-generated goods. Table 3 shows the results for

6 We employ Robinson's (1988) "double residual methodology" to estimate a semiparametric regression model with nonparametric income or asset effect. Then we use the Hardle and Mammen's (1993) test by which we compare the nonparametric and parametric regressions. We cannot reject the null hypothesis that the nonparametric regression and the linear regression give the same fitted equation at 1 per cent statistical significance level in all cases (total expenditure and the sum of categorized expenditures; bought/bartered goods and self-produced goods). Hence, we conclude that our linear regression results are valid. The results are available upon request. 
bought/bartered goods. There are several statistically significant coefficients such as total income in 2007 and a provincial dummy variable. Also, a larger household size corresponds to a lower expenditure gap in seven out of eight specifications. That is, the long-recall expenditures variable compared to the short-recall expenditures variable is lower for larger households, a finding consistent with Gibson (2002). This implies that including the household size as one of the independent variables would be effective in mitigating the long recall bias. In half of the F-test results, we reject jointly zero coefficients strongly, suggesting that $v^{L}-v^{S}$ is correlated with the observed variables more frequently than that in Table 1. The joint test results show that we reject the jointly zero coefficients strongly. However, the exclusion of income, household size, and province dummy variables provides us with the joint insignificance of other independent variables.

The results for self-generated goods reported in Table 4, both the OLS and median regressions, show that asset, income, and province dummy variables have statistically significant coefficients, and that, the joint $\mathrm{F}$ test results indicate that $v^{L}-v^{S}$ is correlated with the observables. Hence, there is a systematic bias either for long recall or short recall variable or both. Once we exclude asset, current income, and province dummy variables, other independent variables become jointly insignificant in half of the specifications.

To summarize, our estimation results offer two suggestions with practical convenience. First, asking total expenditure, rather than categorized expenditures, would not cause long recall errors that are worse than short recall errors in terms of systematic bias. This is especially true for bought/bartered consumption expenditures. This implies that when asking retrospective expenditures questions, it is better to ask total expenditure rather than categorized expenditures when we only have access to long recall data. The 
result may be seen as consistent with De Mel, Mckenzie and Woodruff (2009), which employed data from two panel surveys of Sri Lankan micro-enterprises and found that simply asking the total profits provides a more accurate measure of firm profits than do detailed questions on revenues and expenses.

Second, in regression analyses, the inclusion of household size, asset, income, and geographical dummy variables may mitigate the estimation bias arising from the correlation between the observed independent variables $X$ and long recall errors $v^{L}$. This can be confirmed as follows. Using long recall variable $y^{L}$ for $y$, we may have $E\left(v^{L} \mid X\right) \neq 0$, even if $E(u \mid X)=0$ holds. However, since $E\left(v^{L}-v^{S} \mid X\right)=f(\xi)$, where $\xi$ represents household size, asset, income and geographical dummy variables, we have $E\left(v^{L} \mid X\right)=E\left(v^{S} \mid X\right)+f(\xi)$; thus, it is sufficient to consider $E\left(v^{S} \mid X\right)$ with a set of control variables, $\xi$. It follows that long recall errors will be mitigated even if $E\left(v^{S} \mid X\right) \neq 0$.

Tests of Mean-Reverting Measurement Errors

To test the existence of mean reverting measurement errors, we follow Gibson and Kim $(2007,2010)$ and estimate equation (4). We simply regress the gap between the long recall expenditures variable from the RIETI-CAP data and the short recall expenditures variable from VHLSS 2006 on the short recall expenditures variable from VHLSS 2006.

The estimation results are shown in Table 5. For total expenditure, we cannot reject the null hypothesis that the estimated $\lambda$ is one (specification (1) and (2)). On the other hand, for the sum of categorized expenditures on bought/bartered goods, the estimation result shows that $\lambda<1$ with unadjusted regular standard errors, although we cannot reject the null 
hypothesis $\lambda=1$ with robust standard errors (specification (3)) in most cases. These results suggest that the sum of categorized expenditures involves a mean-reverting measurement error. Yet, once we include current income, household size, and province fixed effects as control variables, the mean reverting errors disappear even in the case of the unadjusted standard error (Table 6).

\section{Internal Consistencies}

The next issue that arises naturally is to identify the reasons behind the discrepancies between total expenditure data and the sum of categorized expenditures data. To this end, we employ the RIETI-CAP survey to compare the sum of categorized expenditures data from a long questionnaire in 2007 and total expenditure from a single broad "total expenditure" question in 2007. Figures 4 (a) and (b) show bought/bartered goods and selfgenerated goods, respectively. The systematic gap between these two variables implies that item-wise consumption may miss some non-negligible consumption items. This is consistent with Browning, Crossley, and Weber (2003), which suggested that the single broad total expenditure question will pick up unexpected sub-items and will achieve reasonable response rates with substantial valid variance. While some existing studies such as Jolliffe (2001) and Pradhan (2001) compared a long questionnaire with a short questionnaire, no existing study employed single total expenditure for comparison purposes.

We regress the observed gap between the sum of categorized expenditures in 2007 and total expenditure in 2007 on a set of observables based on the RIETI-CAP survey. We 
estimate this model for bought/bartered goods and self-generated goods separately (Nakata, Sawada, and Tanaka, 2010). For bought/bartered goods, median regression results show that households with higher asset holdings or higher income tend to report a larger gap, which is defined as total expenditure minus the sum of categorized expenditures. According to the OLS results, households with a steep income increase report a higher gap. Also, based on the results of F-tests, we reject a null hypothesis in which all coefficients are jointly zero in all specifications. ${ }^{7}$

These results suggest that there are non-negligible internal inconsistencies in the retrospective surveys. This may be caused by missing categories/sub-items in a categorized questionnaire. Together with the results presented in Tables $1-6$, asking for total expenditure data, rather than categorized expenditures, will cause fewer long recall errors to be correlated with household characteristics in a retrospective survey.

\section{Conclusion}

Asking retrospective questions about consumption and income has become an important part of household surveys and research in developing countries. While long recall errors in retrospective data may generate estimation biases, the nature and the relative magnitude of the recall errors are largely unknown, especially in the context of developing countries. To

\footnotetext{
7 With respect to self-generated goods, both the OLS and median regression show that households with a larger asset holding tend to report a higher gap (Nakata, Sawada, and Tanaka, 2010). According to the median regression results, households with lower incomes report a higher gap, rural households report a lower gap, and there is a reporting bias specific to certain occupations such as unskilled workers in the mining, construction, manufacturing, and transportation industries and other unskilled workers. With respect to the overall results, with F-tests, we strongly reject the null hypothesis of the jointly zero coefficients.
} 
fill the gap in the existing studies, we collect unique household data from Vietnam, a resurvey of respondents of the Vietnam Household and Living Standards Survey (VHLSS) 2006. This data set allows us to investigate a variety of errors associated with long recall surveys and the size of consumption categories. Our empirical results suggest that long recall data are no worse than short recall data in terms of endogeneity bias when we ask total expenditure, but not necessarily when we ask categorized expenditures. This is especially true in the case of bought/bartered consumption expenditures. As a byproduct, our results also suggest a need to include assets, income, household size, and province dummies as control variables when using retrospective consumption data controlling independent variables.

We also found that the long recall error in the sum of categorized expenditures is more likely to exhibit mean-reverting patterns. The use of expenditures data with this mean-reverting error as a dependent variable will generate downward bias in estimated coefficient, unlike the attenuation bias arising from classical measurement errors in independent variables. In contrast, retrospective total expenditure data may not suffer from mean reverting measurement errors.

Finally, it is important to note that this paper is based on a particular survey design. In particular, the surveys we use ask item-wise expenditures in a "usual month" approach by asking average of frequency and value of the expenditures during the past 12 months reference period. While this approach overcomes the seasonality issue of consumption and has been widely used in various contexts, more recent studies recommend food consumption surveys to use a shorter reference period so as to improve accuracy (Smith etal. 2014; Conforti etal. 2017). It is therefore worthy to note that the evidence found in 
this study could be potentially affected by the choice of reference period. 


\section{References}

Ahmed, N., Brzozowski, M., \& Crossley, T. (2006). Measurement Errors in Recall Food Consumption Data. IFS Working Paper 06/21.

Attanasio, O., Battistin E., \& Ichimura H. (2007). What Really Happened to Consumption Inequality in the US. In E. R. Berndt \& C. R. Hulten (Eds.), Hard-to-Measure Goods and Services: Essays in Honor of Zvi Griliches (pp. 515-543). National Bureau of Economics Research, Inc.

Attanasio, O., \& Pistaferri L. (2016). Consumption Inequality. Journal of Economic Perspectives, 30(2), 3-28.

Battistin, E. (2003). Errors in Survey Reports of Consumption Expenditures. IFS Working Paper 03/07.

Battistin, E., Raffaele, M., \& Weber, G. (2003). What Do We Learn from Recall Consumption Data? Journal of Human Resources, 38(2), 354-385.

Black, D., Berger, M., \& Scott, F. (2000). Bounding Parameter Estimates with Nonclassical Measurement Error. Journal of the American Statistical Association, 95(451), 739748.

Browning, M., Crossley, T., \& Weber, G. (2003). Asking Consumption Questions in General Purpose Surveys. Economic Journal, 113, F540-F567.

Browning, M., \& Lusardi, A. (1996). Household Saving: Micro Theories and Micro Facts. Journal of Economic Literature, 34, 1797-1855.

Brozozowski, M., Crossley, T. F., \& Winter, J. K. (2017). A Comparison of Recall and Diary Food Expenditure Data. Food Policy, 72, 53-61. 
Chesher, A., \& Schluter, C. (2002). Welfare Measurement and Measurement Error. Review of Economic Studies. 69(2), 357-378.

Conforti, P., Grünberger, K., \& Troubat, N. (2017). The Impact of Survey Characteristics on the Measurement of Food Consumption. Food Policy, 72, 43-52.

Crossley, T. F., \& Winter, J. K. (2015). Asking Households about Expenditures: What Have We Learned? In C. D. Carroll, T. F. Crossley, \& J. Sabelhaus (Eds.), Improving the Measurement of Consumer Expenditures (Vol. 74, pp. 23-50). National Bureau of Economic Research, Inc.

De Mel, S., McKenzie, D. J., \& Woodruff, C. (2009). Measuring Microenterprise Profits: Must We Ask How the Sausage Is Made? Journal of Development Economics, 88, 19-31.

Deaton, A., \& Grosh, M. (2002). Core Modules: Consumption. In M. Grosh \& P. Glewwe (Eds.), Designing Household Survey Questionnaires for Developing Countries: Lessons from 15 years of the Living Standards Measurement Study (Vol. 2, Part 2, 91-134). Washington, DC: World Bank.

Friedman, J., Beegle, K., Weerdt, J. D., \& Gibson, J. (2017). Decomposing Response Error in Food Consumption Measurement: Implications for Survey Design from a Randomized Survey Experiment Tanzania. Food Policy, 72, 94-111.

Gibson, J. (2002). Why Does the Engel Method Work? Food Demand, Economics of Size and Household Survey Methods. Oxford Bulletin of Economics and Statistics, 64(4), 341-359. 
Gibson, J., \& Kim, B. (2007). Measurement Error in Recall Surveys and the Relationship between Household Size and Food Demand. American Journal of Agricultural Economics, 89(2), 473-489.

Gibson, J., \& Kim, B. (2010). Non-Classical Measurement Error in Long-Term Retrospective Recall Surveys. Oxford Bulletin of Economics and Statistics, 72(5), 687-695.

Gibson, J., Beegle, K., De Weerdt, J., \& Friedman, J. (2015). What does Variation in Survey Design Reveal about the Nature of Measurement Errors in Household Consumption? Oxford Bulletin of Economics and Statistics, 77(3), 466-474.

Jolliffe, D. (2001). Measuring Absolute and Relative Poverty: The Sensitivity of Estimated Household Consumption to Survey Design. Journal of Economic and Social Measurement, 27(1/2), 1-23.

Kennickell, A., \& Starr-McCluer, M. (1997). Retrospective Reporting of Household Wealth: Evidence from the 1983-89 Survey of Consumer Finances. Journal of Business and Economic Statistics, 15(4), 452-463.

Nakata, H., Sawada Y., and Tanaka M. (2010). Asking Retrospective Questions in Household Surveys: Evidence from Vietnam. RIETI Discussion Paper Series 10-E008.

Peters, E. (1988). Retrospective Versus Panel Data in Analyzing Lifecycle Events. Journal of Human Resources, 23(4), 488-513.

Pierret, C. R. (2001). Event History Data Survey Recall: An Analysis of the National Longitudinal Survey of Youth 1979 Recall Experiment. Journal of Human Resources, 36(3), 439-466. 
Pradhan, M. (2001). Welfare Analysis with a Proxy Consumption Measure - Evidence from a Repeated Experiment in Indonesia. Tinbergen Institute Discussion Papers 01092/2, Tinbergen Institute.

Smith, J., \& Thomas, D. (2003). Remembrances of Things Past: Test-Retest Reliability of Retrospective Migration Histories. Journal of the Royal Statistical Society: Series A (Statistics in Society), 166(1), 23-49.

Smith, L., \& Dupriez, O., Troubat, N. (2014). Assessment of the Reliability and Relevance of the Food Data Collected in National Household Consumption and Expenditure Surveys. IHSN, FAO, World Bank. 
Table 1. The gap between RIETI-CAP data (long recall) and VHLSS 2006 (short recall) - total expenditure on bought/bartered goods

\begin{tabular}{|c|c|c|c|c|c|c|c|c|}
\hline $\begin{array}{l}\text { Specification } \\
\text { Method }\end{array}$ & $\begin{array}{c}(1) \\
\text { Median reg }\end{array}$ & $\begin{array}{l}(2) \\
\text { OLS }\end{array}$ & $\begin{array}{c}(3) \\
\text { Median reg }\end{array}$ & $\begin{array}{l}(4) \\
\text { OLS }\end{array}$ & $\begin{array}{c}(5) \\
\text { Median reg }\end{array}$ & $\begin{array}{l}(6) \\
\text { OLS }\end{array}$ & $\begin{array}{c}(7) \\
\text { Median reg }\end{array}$ & $\begin{array}{l}(8) \\
\text { OLS }\end{array}$ \\
\hline \multicolumn{9}{|l|}{ (Household's and Head's Characteristics) } \\
\hline Asset in 2007 & $\begin{array}{l}0.656 \\
(5.820)\end{array}$ & $\begin{array}{l}3.791 \\
(8.114)\end{array}$ & $\begin{array}{l}1.262 \\
(4.666)\end{array}$ & $\begin{array}{l}4.747 \\
(8.159)\end{array}$ & $\begin{array}{l}-0.05 \\
(5.692)\end{array}$ & $\begin{array}{l}3.764 \\
(8.170)\end{array}$ & $\begin{array}{l}0.166 \\
(4.130)\end{array}$ & $\begin{array}{l}3.342 \\
(8.103)\end{array}$ \\
\hline Total income in 2007 & $\begin{array}{l}0.13 \\
(0.233)\end{array}$ & $\begin{array}{l}-1.285 \\
(1.123)\end{array}$ & $\begin{array}{l}0.114 \\
(0.194)\end{array}$ & $\begin{array}{l}-1.28 \\
(1.140)\end{array}$ & $\begin{array}{l}0.065 \\
(0.234)\end{array}$ & $\begin{array}{l}-1.287 \\
(1.105)\end{array}$ & $\begin{array}{l}0.13 \\
(0.171)\end{array}$ & $\begin{array}{l}-1.291 \\
(1.129)\end{array}$ \\
\hline Increase in income level between 2006 and 2007 & $\begin{array}{l}-0.02 \\
(0.038)\end{array}$ & $\begin{array}{l}0.2 \\
(0.175)\end{array}$ & $\begin{array}{l}-0.019 \\
(0.032)\end{array}$ & $\begin{array}{l}0.194 \\
(0.177)\end{array}$ & $\begin{array}{l}-0.006 \\
(0.038)\end{array}$ & $\begin{array}{l}0.198 \\
(0.171)\end{array}$ & $\begin{array}{l}-0.019 \\
(0.028)\end{array}$ & $\begin{array}{l}0.195 \\
(0.174)\end{array}$ \\
\hline Number of household members & $\begin{array}{l}-35.565 \\
(198.576)\end{array}$ & $\begin{array}{l}-295.796 \\
(233.055)\end{array}$ & $\begin{array}{l}-141.548 \\
(169.421)\end{array}$ & $\begin{array}{l}-363.226 \\
(258.143)\end{array}$ & $\begin{array}{l}-61.901 \\
(203.960)\end{array}$ & $\begin{array}{l}-347.437 \\
(248.359)\end{array}$ & $\begin{array}{l}-44.858 \\
(146.790)\end{array}$ & $\begin{array}{l}-359.451 \\
(242.041)\end{array}$ \\
\hline $\begin{array}{l}\text { The highest education level among household members is at least } \\
\text { secondary school (dummy) }\end{array}$ & & & & & & & $\begin{array}{l}1,246.092^{* *} \\
(553.653)\end{array}$ & $\begin{array}{l}1,280.511^{*} \\
(689.523)\end{array}$ \\
\hline $\begin{array}{l}\text { Head's occupation dummy I (unskilled sales and service } \\
\text { worker) }\end{array}$ & $\begin{array}{l}1,332.60 \\
(1,451.755)\end{array}$ & $\begin{array}{l}3,100.67 \\
(4,688.626)\end{array}$ & $\begin{array}{l}749.742 \\
(1,182.733)\end{array}$ & $\begin{array}{l}2,729.02 \\
(4,842.467)\end{array}$ & $\begin{array}{l}1,234.60 \\
(1,454.51)\end{array}$ & $\begin{array}{l}2,950.58 \\
(4,720.122)\end{array}$ & $\begin{array}{l}1,313.57 \\
(1,063.554)\end{array}$ & $\begin{array}{l}2,845.65 \\
(4,718.289)\end{array}$ \\
\hline $\begin{array}{l}\text { Head's occupation dummy II (unskilled agriculture, forestry, } \\
\text { or aquaculture worker) }\end{array}$ & $\begin{array}{l}-374.408 \\
(701.504)\end{array}$ & $\begin{array}{l}-622.525 \\
(776.835)\end{array}$ & $\begin{array}{l}-505.613 \\
(579.338)\end{array}$ & $\begin{array}{l}-733.018 \\
(780.562)\end{array}$ & $\begin{array}{l}-462.565 \\
(702.223)\end{array}$ & $\begin{array}{l}-668.399 \\
(790.772)\end{array}$ & $\begin{array}{l}-433.424 \\
(511.815)\end{array}$ & $\begin{array}{l}-573.257 \\
(785.938)\end{array}$ \\
\hline Head’s occupation dummy III (other unskilled worker) & $\begin{array}{l}1,552.83 \\
(1,344.885) \\
\end{array}$ & $\begin{array}{l}-822.026 \\
(1,232.530)\end{array}$ & $\begin{array}{l}659.246 \\
(1,125.832)\end{array}$ & $\begin{array}{l}-1,067.55 \\
(1,320.54)\end{array}$ & $\begin{array}{l}1,283.26 \\
(1,347.65)\end{array}$ & $\begin{array}{l}-907.641 \\
(1,232.729)\end{array}$ & $\begin{array}{l}1,302.36 \\
(981.187)\end{array}$ & $\begin{array}{l}-784.867 \\
(1,229.380)\end{array}$ \\
\hline \multicolumn{9}{|l|}{ (Geography Variables) } \\
\hline Rural (dummy) & $\begin{array}{l}-331.887 \\
(1,217.736)\end{array}$ & $\begin{array}{l}-1,153.27 \\
(1,790.082)\end{array}$ & $\begin{array}{l}-350.431 \\
(1,002.012)\end{array}$ & $\begin{array}{l}-1,530.17 \\
(1,918.24)\end{array}$ & $\begin{array}{l}-376.296 \\
(1,218.84)\end{array}$ & $\begin{array}{l}-1,273.85 \\
(1,857.699)\end{array}$ & $\begin{array}{l}-318.856 \\
(895.723)\end{array}$ & $\begin{array}{l}-1,228.49 \\
(1,856.783)\end{array}$ \\
\hline Kinh ethnicity dummy & $\begin{array}{l}124.597 \\
(1,158.116)\end{array}$ & $\begin{array}{l}835.551 \\
(1,199.134)\end{array}$ & $\begin{array}{l}430.942 \\
(984.238)\end{array}$ & $\begin{array}{l}660.464 \\
(1,201.36)\end{array}$ & $\begin{array}{l}-458.933 \\
(1,206.50)\end{array}$ & $\begin{array}{l}351.515 \\
(1,162.544)\end{array}$ & $\begin{array}{l}-63.221 \\
(867.241)\end{array}$ & $\begin{array}{l}616.139 \\
(1,178.743)\end{array}$ \\
\hline Ha Tay province dummy & $\begin{array}{l}-692.625 \\
(845.375)\end{array}$ & $\begin{array}{l}-1,939.63 * * \\
(896.749)\end{array}$ & $\begin{array}{l}-819.407 \\
(692.020)\end{array}$ & $\begin{array}{l}-2,057.37^{* *} \\
(902.762)\end{array}$ & $\begin{array}{l}-963.435 \\
(853.656)\end{array}$ & $\begin{array}{l}-2,340.81 * * \\
(956.944)\end{array}$ & $\begin{array}{l}-1,025.38 \\
(623.258)\end{array}$ & $\begin{array}{l}-2,268.61 * * \\
(924.156)\end{array}$ \\
\hline Lao Cai province dummy & $\begin{array}{l}-1,702.41 \\
(1,121.627)\end{array}$ & $\begin{array}{l}-755.242 \\
(1,383.048)\end{array}$ & $\begin{array}{l}-1,867.06^{* *} \\
(924.997)\end{array}$ & $\begin{array}{l}-1,077.22 \\
(1,387.469)\end{array}$ & $\begin{array}{l}-2,016.54 * \\
(1,137.37)\end{array}$ & $\begin{array}{l}-951.498 \\
(1,368.448)\end{array}$ & $\begin{array}{l}-1,896.46 * * \\
(823.747)\end{array}$ & $\begin{array}{l}-870.998 \\
(1,366.983)\end{array}$ \\
\hline Nghe An province dummy & $\begin{array}{l}-1,286.53 \\
(835.230)\end{array}$ & $\begin{array}{l}-357.63 \\
(1,140.085)\end{array}$ & $\begin{array}{l}-1,327.47^{*} \\
(700.490)\end{array}$ & $\begin{array}{l}-444.908 \\
(1,052.359)\end{array}$ & $\begin{array}{l}-1,424.05^{*} \\
(862.722)\end{array}$ & $\begin{array}{l}-867.916 \\
(1,138.707)\end{array}$ & $\begin{array}{l}-1,433.99 * * \\
(613.865)\end{array}$ & $\begin{array}{l}-615.175 \\
(1,127.370)\end{array}$ \\
\hline
\end{tabular}

Note: Standard errors (median regression) or robust standard errors (OLS) in brackets.

* significant at $10 \% ; * *$ significant at $5 \% ; * * *$ significant at $1 \%$ 
Table 1. The gap between RIETI-CAP data (long recall) and VHLSS 2006 (short recall) - total expenditure on bought/bartered goods (continued)

\begin{tabular}{|c|c|c|c|c|c|c|c|c|}
\hline Specification & $(1)$ & $(2)$ & (3) & $(4)$ & $(5)$ & $(6)$ & $(7)$ & $(8)$ \\
\hline Method & Median reg & OLS & Median reg & OLS & Median reg & OLS & Median reg & OLS \\
\hline \multicolumn{9}{|l|}{ (Conditions of Actual Interviews) } \\
\hline Translator required (dummy) & $\begin{array}{l}-1,629.08 \\
(1,875.595)\end{array}$ & $\begin{array}{l}-1,898.53 \\
(1,338.717)\end{array}$ & $\begin{array}{l}-1,125.53 \\
(1,545.283)\end{array}$ & $\begin{array}{l}-1,600.57 \\
(1,391.029)\end{array}$ & $\begin{array}{l}-819.774 \\
(1,889.26)\end{array}$ & $\begin{array}{l}-1,292.84 \\
(1,436.665)\end{array}$ & $\begin{array}{l}-552.746 \\
(1,375.285)\end{array}$ & $\begin{array}{l}-1,446.55 \\
(1,431.706)\end{array}$ \\
\hline Female respondent & $\begin{array}{l}436.152 \\
(628.549)\end{array}$ & $\begin{array}{l}-840.371 \\
(961.909)\end{array}$ & & & & & & \\
\hline Respondent is head's son (dummy) & & & $\begin{array}{l}-871.24 \\
(1,713.657)\end{array}$ & $\begin{array}{l}-1,887.35 \\
(2,231.290)\end{array}$ & $\begin{array}{l}644.982 \\
(1,858.84)\end{array}$ & $\begin{array}{l}-672.391 \\
(1,378.607)\end{array}$ & $\begin{array}{l}-555.91 \\
(1,259.692)\end{array}$ & $\begin{array}{l}-2,301.319^{*} \\
(1,293.686)\end{array}$ \\
\hline Respondent is head's daughter (dummy) & & & $\begin{array}{l}-3,182.11 \\
(2,550.779)\end{array}$ & $\begin{array}{l}-2,114.82 \\
(3,558.088)\end{array}$ & $\begin{array}{l}-1,736.82 \\
(2,980.69)\end{array}$ & $\begin{array}{l}-857.416 \\
(3,142.257)\end{array}$ & $\begin{array}{l}-2,984.04 \\
(2,119.315)\end{array}$ & $\begin{array}{l}-2,477.54 \\
(3,043.399)\end{array}$ \\
\hline Respondent is female head or wife (dummy) & & & $\begin{array}{l}3,612.414 * * \\
(1,651.359)\end{array}$ & $\begin{array}{l}1,764.71 \\
(2,309.862)\end{array}$ & $\begin{array}{l}334.616 \\
(1,178.03)\end{array}$ & $\begin{array}{l}457.659 \\
(1,179.652)\end{array}$ & $\begin{array}{l}643.244 \\
(465.601)\end{array}$ & $\begin{array}{l}-835.171 \\
(984.624)\end{array}$ \\
\hline Respondent's age*Respondent is female head or wife (dummy) & & & $\begin{array}{l}-66.554 * * \\
(25.757)\end{array}$ & $\begin{array}{l}-48.723 \\
(36.243)\end{array}$ & & & & \\
\hline Respondent's age*Respondent is male head or husband (dummy) & & & $\begin{array}{l}-4.787 \\
(20.677)\end{array}$ & $\begin{array}{l}5.523 \\
(39.670)\end{array}$ & & & & \\
\hline $\begin{array}{l}\text { Respondent is female head or wife and has graduated } \\
\text { from primary school (dummy) } \\
\text { Respondent is male head or husband and has graduated } \\
\text { from primary school (dummy) }\end{array}$ & & & & & $\begin{array}{l}1,645.39 \\
(1,069.46) \\
1,211.35 \\
(952.003)\end{array}$ & $\begin{array}{l}254.212 \\
(1,123.397) \\
2,023.837^{*} \\
(1,142.756)\end{array}$ & & \\
\hline Constant & $\begin{array}{l}3,813.697^{*} \\
(2,167.223)\end{array}$ & $\begin{array}{l}6,232.980 * * * \\
(2,159.954)\end{array}$ & $\begin{array}{l}4,407.074 * * \\
(2,073.374)\end{array}$ & $\begin{array}{l}7,085.133^{* *} \\
(3,307.659)\end{array}$ & $\begin{array}{l}3,599.34 \\
(2,292.99)\end{array}$ & $\begin{array}{l}5,878.86^{* *} \\
(2,357.908)\end{array}$ & $\begin{array}{l}3,039.820^{*} \\
(1,655.569)\end{array}$ & $\begin{array}{l}6,050.23 * * * \\
(2,254.637)\end{array}$ \\
\hline Observations & 396 & 396 & 396 & 396 & 396 & 396 & 396 & 396 \\
\hline F test: coeff. of all var $=0$ & 0.9 & 1.54 & 1.53 & 1.26 & 0.86 & 1.29 & 1.76 & 1.35 \\
\hline Prob $>$ F & {$[0.563]$} & [0.095] & [0.076] & {$[0.214]$} & [0.627] & [0.191] & {$[0.032]$} & {$[0.158]$} \\
\hline F test: zero coeff of var other than province dummies & 0.67 & 0.97 & 1.26 & 0.86 & 0.77 & 0.83 & 1.48 & 0.94 \\
\hline Prob $>$ F & {$[0.77]$} & [0.47] & {$[0.22]$} & {$[0.60]$} & {$[0.72]$} & {$[0.62]$} & {$[0.12]$} & {$[0.52]$} \\
\hline R-squared & & 0.06 & & 0.07 & & 0.07 & & 0.07 \\
\hline
\end{tabular}

Note: Standard errors (median regression) or robust standard errors (OLS) in brackets.

$*$ significant at $10 \% ; * *$ significant at $5 \% ; * * *$ significant at $1 \%$ 
Table 2. The gap between RIETI-CAP data (long recall) and VHLSS 2006 (short recall) - total consumption of self-generated goods

\begin{tabular}{|c|c|c|c|c|c|c|c|c|}
\hline $\begin{array}{l}\text { Specification } \\
\text { Method }\end{array}$ & $\begin{array}{c}(1) \\
\text { Median reg }\end{array}$ & $\begin{array}{l}\text { (2) } \\
\text { OLS }\end{array}$ & $\begin{array}{c}(3) \\
\text { Median reg }\end{array}$ & $\begin{array}{l}\text { (4) } \\
\text { OLS }\end{array}$ & $\begin{array}{c}(5) \\
\text { Median reg }\end{array}$ & $\begin{array}{l}\text { (6) } \\
\text { OLS }\end{array}$ & $\begin{array}{c}(7) \\
\text { Median reg }\end{array}$ & $\begin{array}{l}\text { (8) } \\
\text { OLS }\end{array}$ \\
\hline \multicolumn{9}{|l|}{ (Household's and Head's Characteristics) } \\
\hline Asset in 2007 & $\begin{array}{l}-8.132 * * * \\
(2.951)\end{array}$ & $\begin{array}{l}-10.231^{* * *} \\
(2.869)\end{array}$ & $\begin{array}{l}-8.428 * * * \\
(2.581)\end{array}$ & $\begin{array}{l}-9.571 * * * \\
(2.785)\end{array}$ & $\begin{array}{l}-7.944 * * * \\
(2.752)\end{array}$ & $\begin{array}{l}-9.568 * * * \\
(2.797)\end{array}$ & $\begin{array}{l}-7.840 * * * \\
(2.552)\end{array}$ & $\begin{array}{l}-9.697 * * * \\
(2.871)\end{array}$ \\
\hline Total income in 2007 & $\begin{array}{l}0.328^{*} \\
(0.167)\end{array}$ & $\begin{array}{l}0.373^{*} \\
(0.195)\end{array}$ & $\begin{array}{l}0.362 * * \\
(0.153)\end{array}$ & $\begin{array}{l}0.377 * \\
(0.197)\end{array}$ & $\begin{array}{l}0.331 * * \\
(0.165)\end{array}$ & $\begin{array}{l}0.355^{*} \\
(0.194)\end{array}$ & $\begin{array}{l}0.320 * * \\
(0.153)\end{array}$ & $\begin{array}{l}0.381 * \\
(0.197)\end{array}$ \\
\hline Increase in income level between 2006 and 2007 & $\begin{array}{l}-0.029 \\
(0.032)\end{array}$ & $\begin{array}{l}-0.043 \\
(0.039)\end{array}$ & $\begin{array}{l}-0.036 \\
(0.030)\end{array}$ & $\begin{array}{l}-0.048 \\
(0.040)\end{array}$ & $\begin{array}{l}-0.029 \\
(0.032)\end{array}$ & $\begin{array}{l}-0.04 \\
(0.039)\end{array}$ & $\begin{array}{l}-0.026 \\
(0.030)\end{array}$ & $\begin{array}{l}-0.045 \\
(0.040)\end{array}$ \\
\hline Number of household members & $\begin{array}{l}122.763 \\
(104.422)\end{array}$ & $\begin{array}{l}15.841 \\
(112.814)\end{array}$ & $\begin{array}{l}92.917 \\
(98.414)\end{array}$ & $\begin{array}{l}-26.285 \\
(130.894)\end{array}$ & $\begin{array}{l}121.171 \\
(104.168)\end{array}$ & $\begin{array}{l}39.074 \\
(111.894)\end{array}$ & $\begin{array}{l}186.303^{*} \\
(96.801)\end{array}$ & $\begin{array}{l}29.453 \\
(115.405)\end{array}$ \\
\hline $\begin{array}{l}\text { The highest education level among household members is at least } \\
\text { secondary school (dummy) }\end{array}$ & & & & & & & $\begin{array}{l}-444.895 \\
(356.688)\end{array}$ & $\begin{array}{l}-174.075 \\
(509.866)\end{array}$ \\
\hline $\begin{array}{l}\text { Head's occupation dummy I (unskilled sales and service } \\
\text { worker) }\end{array}$ & $\begin{array}{l}381.113 \\
(868.237)\end{array}$ & $\begin{array}{l}810.603 \\
(2,090.364)\end{array}$ & $\begin{array}{l}156.088 \\
(767.639)\end{array}$ & $\begin{array}{l}478.725 \\
(1,921.268)\end{array}$ & $\begin{array}{l}210.568 \\
(814.970)\end{array}$ & $\begin{array}{l}749.703 \\
(2,086.465)\end{array}$ & $\begin{array}{l}317.016 \\
(756.169)\end{array}$ & $\begin{array}{l}721.69 \\
(2,110.967)\end{array}$ \\
\hline $\begin{array}{l}\text { Head's occupation dummy II (unskilled agriculture, forestry, } \\
\text { or aquaculture worker) }\end{array}$ & $\begin{array}{l}287.046 \\
(365.583)\end{array}$ & $\begin{array}{l}48.096 \\
(508.902)\end{array}$ & $\begin{array}{l}265.321 \\
(339.941)\end{array}$ & $\begin{array}{l}-38.43 \\
(529.449)\end{array}$ & $\begin{array}{l}267.907 \\
(363.179)\end{array}$ & $\begin{array}{l}-11.776 \\
(528.482)\end{array}$ & $\begin{array}{l}229.021 \\
(334.615)\end{array}$ & $\begin{array}{l}-39.915 \\
(522.678)\end{array}$ \\
\hline Head's occupation dummy III (other unskilled worker) & $\begin{array}{l}306.309 \\
(729.609)\end{array}$ & $\begin{array}{l}1,191.33 \\
(1,578.882)\end{array}$ & $\begin{array}{l}18.5 \\
(679.923) \\
\end{array}$ & $\begin{array}{l}938.728 \\
(1,644.465) \\
\end{array}$ & $\begin{array}{l}260.198 \\
(708.598) \\
\end{array}$ & $\begin{array}{l}1,195.00 \\
(1,580.399) \\
\end{array}$ & $\begin{array}{l}259.213 \\
(649.973) \\
\end{array}$ & $\begin{array}{l}1,139.23 \\
(1,596.93) \\
\end{array}$ \\
\hline \multicolumn{9}{|l|}{ (Geography Variables) } \\
\hline Rural (dummy) & $\begin{array}{l}-784.678 \\
(766.128)\end{array}$ & $\begin{array}{l}-897.751 \\
(1,308.644)\end{array}$ & $\begin{array}{l}-456.182 \\
(706.808)\end{array}$ & $\begin{array}{l}-1,253.78 \\
(1,328.921)\end{array}$ & $\begin{array}{l}-762.513 \\
(740.417)\end{array}$ & $\begin{array}{l}-1,151.89 \\
(1,371.724)\end{array}$ & $\begin{array}{l}-863.504 \\
(713.163)\end{array}$ & $\begin{array}{l}-1,182.65 \\
(1,356.019)\end{array}$ \\
\hline Kinh ethnicity dummy & $\begin{array}{l}-53.375 \\
(612.087)\end{array}$ & $\begin{array}{l}1,066.28 \\
(949.081)\end{array}$ & $\begin{array}{l}-49.072 \\
(570.753)\end{array}$ & $\begin{array}{l}1,049.46 \\
(957.671)\end{array}$ & $\begin{array}{l}-204.736 \\
(603.770)\end{array}$ & $\begin{array}{l}1,003.14 \\
(923.277)\end{array}$ & $\begin{array}{l}-185.256 \\
(559.070)\end{array}$ & $\begin{array}{l}981.275 \\
(943.200)\end{array}$ \\
\hline Ha Tay province dummy & -632.409 & & $-661.405^{*}$ & - & -638.52 & & $-721.577 *$ & \\
\hline Lao Cai province dummy & $\begin{array}{l}(432.730) \\
-750.631 \\
(614.247)\end{array}$ & $\begin{array}{l}1,328.255^{* * *} \\
(504.182) \\
270.176 \\
(1,239.001)\end{array}$ & $\begin{array}{l}(397.323) \\
-639.419 \\
(574.439)\end{array}$ & $\begin{array}{l}1,351.880^{* *} \\
(522.291) \\
243.011 \\
(1,249.342)\end{array}$ & $\begin{array}{l}(434.901) \\
-886.282 \\
(603.474)\end{array}$ & $\begin{array}{l}1,295.472 * * \\
(512.772) \\
353.425 \\
(1,236.487)\end{array}$ & $\begin{array}{l}(399.792) \\
-1,110.214^{* *} \\
(558.074)\end{array}$ & $\begin{array}{l}1,307.0 * * * \\
(495.073) \\
212.313 \\
(1,258.618)\end{array}$ \\
\hline Nghe An province dummy & $\begin{array}{l}1,149.559^{* * *} \\
(435.575)\end{array}$ & -883.688 & $\begin{array}{l}1,254.652 * * * \\
(404.864)\end{array}$ & -838.706 & $\begin{array}{l}1,174.702 * * * \\
(443.029)\end{array}$ & -855.676 & $\begin{array}{l}1,267.871 * * * \\
(393.866)\end{array}$ & -883.278 \\
\hline
\end{tabular}

Note: Standard errors (median regression) or robust standard errors (OLS) in brackets.

$*$ significant at $10 \%$; ** significant at 5\%; *** significant at $1 \%$ 
Table 2. The gap between RIETI-CAP data (long recall) and VHLSS 2006 (short recall) - total consumption of self-generated goods (continued)

\begin{tabular}{|c|c|c|c|c|c|c|c|c|}
\hline Specification & $(1)$ & (2) & (3) & (4) & $(5)$ & (6) & (7) & $(8)$ \\
\hline Method & Median reg & OLS & Median reg & OLS & Median reg & OLS & Median reg & OLS \\
\hline \multicolumn{9}{|l|}{ (Conditions of Actual Interviews) } \\
\hline Translator required (dummy) & $\begin{array}{l}-1,065.04 \\
(935.139)\end{array}$ & $\begin{array}{l}-1,440.506^{*} \\
(834.926)\end{array}$ & $\begin{array}{l}-1,132.08 \\
(861.102)\end{array}$ & $\begin{array}{l}-1,341.65 \\
(850.569)\end{array}$ & $\begin{array}{l}-1,135.83 \\
(919.731)\end{array}$ & $\begin{array}{l}-1,540.884^{*} \\
(823.756)\end{array}$ & $\begin{array}{l}-1,188.05 \\
(860.719)\end{array}$ & $\begin{array}{l}-1,496.201^{*} \\
(822.792)\end{array}$ \\
\hline Female respondent & $\begin{array}{l}-183.841 \\
(328.371)\end{array}$ & $\begin{array}{l}-773.130^{*} \\
(438.052)\end{array}$ & & & & & & \\
\hline Respondent is head's son (dummy) & & & $\begin{array}{l}1,177.84 \\
(985.928)\end{array}$ & $\begin{array}{l}-1,105.73 \\
(1,107.963)\end{array}$ & $\begin{array}{l}927.375 \\
(932.683)\end{array}$ & $\begin{array}{l}-518.5 \\
(908.541)\end{array}$ & $\begin{array}{l}905.346 \\
(796.738)\end{array}$ & $\begin{array}{l}-664.207 \\
(846.484)\end{array}$ \\
\hline Respondent is head's daughter (dummy) & & & $\begin{array}{l}-1,968.01 \\
(1,483.807)\end{array}$ & $\begin{array}{l}-3,464.484 * * * \\
(1,031.298)\end{array}$ & $\begin{array}{l}-2,322.57 \\
(1,522.960)\end{array}$ & $\begin{array}{l}-2,895.337 * * * \\
(941.332)\end{array}$ & $\begin{array}{l}-2,157.61 \\
(1,378.057)\end{array}$ & $\begin{array}{l}-3,033.4^{* * * *} \\
(808.444)\end{array}$ \\
\hline Respondent is female head or wife (dummy) & & & $\begin{array}{l}439.039 \\
(938.591)\end{array}$ & $\begin{array}{l}135.366 \\
(1,991.135)\end{array}$ & $\begin{array}{l}-103.865 \\
(599.283)\end{array}$ & $\begin{array}{l}-35.99 \\
(751.013)\end{array}$ & $\begin{array}{l}-181.105 \\
(303.189)\end{array}$ & $\begin{array}{l}-774.108^{*} \\
(452.678)\end{array}$ \\
\hline $\begin{array}{l}\text { Respondent's age*Respondent is female head or } \\
\text { wife (dummy) }\end{array}$ & & & $\begin{array}{l}-8.503 \\
(14.600)\end{array}$ & $\begin{array}{l}-25.968 \\
(33.889)\end{array}$ & & & & \\
\hline Respondent's age*Respondent is male head or husband (dummy) & & & $\begin{array}{l}0.779 \\
(11.902)\end{array}$ & $\begin{array}{l}-8.525 \\
(13.534)\end{array}$ & & & & \\
\hline $\begin{array}{l}\text { Respondent is female head or wife and has graduated } \\
\text { from primary school (dummy) } \\
\text { Respondent is male head or husband and has graduated } \\
\text { from primary school (dummy) }\end{array}$ & & & & & $\begin{array}{l}-167.738 \\
(553.165) \\
-125.98 \\
(499.920)\end{array}$ & $\begin{array}{l}-850.633 \\
(697.115) \\
221.794 \\
(618.448)\end{array}$ & & \\
\hline Constant & $\begin{array}{l}2,279.814^{*} \\
(1,177.127)\end{array}$ & $\begin{array}{l}2,944.671 * * \\
(1,397.870)\end{array}$ & $\begin{array}{l}2,099.563 * \\
(1,228.133)\end{array}$ & $\begin{array}{l}3,984.966^{* *} \\
(1,674.451)\end{array}$ & $\begin{array}{l}2,547.811^{* *} \\
(1,197.329)\end{array}$ & $\begin{array}{l}2,998.585^{*} \\
(1,607.300)\end{array}$ & $\begin{array}{l}2,722.817 * * \\
(1,107.104)\end{array}$ & $\begin{array}{l}3,457.11 * * \\
(1,535.223)\end{array}$ \\
\hline Observations & 362 & 362 & 362 & 362 & 362 & 362 & 362 & 362 \\
\hline F test: coeff. of all var $=0$ & 2.53 & 3.18 & 2.62 & 3.79 & 2.29 & 3.98 & 3.11 & 4.07 \\
\hline Prob $>$ F & [0.002] & {$[0.000]$} & [0.000] & {$[0.000]$} & [0.002] & {$[0.000]$} & {$[0.000]$} & [0.000] \\
\hline F test: zero coeff of var other than asset, income and province dummies & 0.71 & 1.07 & 0.85 & 2.64 & 0.87 & 2.74 & 1.12 & 2.96 \\
\hline Prob $>$ F & {$[0.69]$} & {$[0.38]$} & {$[0.61]$} & {$[0.002]$} & {$[0.59]$} & {$[0.001]$} & {$[0.339]$} & {$[0.001]$} \\
\hline R-squared & & 0.06 & & 0.06 & & 0.06 & & 0.06 \\
\hline
\end{tabular}

Note: Standard errors (median regression) or robust standard errors (OLS) in brackets.

* significant at $10 \% ; * *$ significant at $5 \% ; * * *$ significant at $1 \%$ 
Table 3. The gap between RIETI-CAP data (long recall) and VHLSS 2006 (short recall) - sum of categorized expenditures on bought/bartered goods

\begin{tabular}{|c|c|c|c|c|c|c|c|c|}
\hline $\begin{array}{l}\text { Specification } \\
\text { Method }\end{array}$ & $\begin{array}{c}(1) \\
\text { Median reg }\end{array}$ & $\begin{array}{l}(2) \\
\text { OLS }\end{array}$ & $\begin{array}{c}(3) \\
\text { Median reg }\end{array}$ & $\begin{array}{l}(4) \\
\text { OLS }\end{array}$ & $\begin{array}{c}(5) \\
\text { Median reg }\end{array}$ & $\begin{array}{l}(6) \\
\text { OLS }\end{array}$ & $\begin{array}{c}(7) \\
\text { Median reg }\end{array}$ & $\begin{array}{l}(8) \\
\text { OLS }\end{array}$ \\
\hline \multicolumn{9}{|l|}{ (Household's and Head's Characteristics) } \\
\hline Asset in 2007 & $\begin{array}{l}2.219 \\
(6.320)\end{array}$ & $\begin{array}{l}3.787 \\
(7.878)\end{array}$ & $\begin{array}{l}3.738 \\
(4.075)\end{array}$ & $\begin{array}{l}4.68 \\
(7.703)\end{array}$ & $\begin{array}{l}1.167 \\
(5.508)\end{array}$ & $\begin{array}{l}3.834 \\
(7.615)\end{array}$ & $\begin{array}{l}1.374 \\
(4.850)\end{array}$ & $\begin{array}{l}3.592 \\
(7.628)\end{array}$ \\
\hline Total income in 2007 & $\begin{array}{l}-0.597 * * * \\
(0.203)\end{array}$ & $\begin{array}{l}-1.664 \\
(1.091)\end{array}$ & $\begin{array}{l}-0.617 * * * \\
(0.132)\end{array}$ & $\begin{array}{l}-1.67 \\
(1.107)\end{array}$ & $\begin{array}{l}-0.628 * * * \\
(0.177)\end{array}$ & $\begin{array}{l}-1.662 \\
(1.090)\end{array}$ & $\begin{array}{l}-0.583 * * * \\
(0.156)\end{array}$ & $\begin{array}{l}-1.666 \\
(1.095)\end{array}$ \\
\hline Increase in income level between 2006 and 2007 & $\begin{array}{l}0.017 \\
(0.033)\end{array}$ & $\begin{array}{l}0.172 \\
(0.163)\end{array}$ & $\begin{array}{l}0.015 \\
(0.021)\end{array}$ & $\begin{array}{l}0.167 \\
(0.164)\end{array}$ & $\begin{array}{l}0.021 \\
(0.029)\end{array}$ & $\begin{array}{l}0.17 \\
(0.162)\end{array}$ & $\begin{array}{l}0.014 \\
(0.025)\end{array}$ & $\begin{array}{l}0.169 \\
(0.162)\end{array}$ \\
\hline Number of household members & $\begin{array}{l}-212.248 \\
(173.332)\end{array}$ & $\begin{array}{l}-462.169 * \\
(244.055)\end{array}$ & $\begin{array}{l}-413.684 * * * \\
(115.279)\end{array}$ & $\begin{array}{l}-559.745^{* *} \\
(265.037)\end{array}$ & $\begin{array}{l}-266.681 * \\
(153.057)\end{array}$ & $\begin{array}{l}-493.057 * \\
(263.960)\end{array}$ & $\begin{array}{l}-248.920 * \\
(135.794)\end{array}$ & $\begin{array}{l}-502.85^{*} \\
(261.19)\end{array}$ \\
\hline $\begin{array}{l}\text { The highest education level among household members is at least } \\
\text { secondary school (dummy) }\end{array}$ & & & & & & & $\begin{array}{l}698.081 \\
(497.678)\end{array}$ & $\begin{array}{l}697.316 \\
(775.25)\end{array}$ \\
\hline $\begin{array}{l}\text { Head's occupation dummy I (unskilled sales and service } \\
\text { worker) }\end{array}$ & $\begin{array}{l}1,792.19 \\
(1,237.544)\end{array}$ & $\begin{array}{l}3,398.87 \\
(4,812.542)\end{array}$ & $\begin{array}{l}514.048 \\
(817.288)\end{array}$ & $\begin{array}{l}2,965.30 \\
(4,961.484)\end{array}$ & $\begin{array}{l}1,278.54 \\
(1,096.342)\end{array}$ & $\begin{array}{l}3,299.99 \\
(4,860.114)\end{array}$ & $\begin{array}{l}910.536 \\
(963.114)\end{array}$ & $\begin{array}{l}3,248.66 \\
(4,846.5)\end{array}$ \\
\hline $\begin{array}{l}\text { Head's occupation dummy II (unskilled agriculture, forestry, } \\
\text { Or aquaculture worker) }\end{array}$ & $\begin{array}{l}-446.242 \\
(602.111)\end{array}$ & $\begin{array}{l}-913.575 \\
(791.194)\end{array}$ & $\begin{array}{l}-1,041.385^{* * *} \\
(393.067)\end{array}$ & $\begin{array}{l}-969.032 \\
(808.147)\end{array}$ & $\begin{array}{l}-563.237 \\
(528.862)\end{array}$ & $\begin{array}{l}-899.5 \\
(809.426)\end{array}$ & $\begin{array}{l}-515.845 \\
(466.594)\end{array}$ & $\begin{array}{l}-844.241 \\
(809.32)\end{array}$ \\
\hline Head's occupation dummy III (other unskilled worker) & $\begin{array}{l}719.736 \\
(1,177.815)\end{array}$ & $\begin{array}{l}-271.089 \\
(1,123.242)\end{array}$ & $\begin{array}{l}1,013.43 \\
(757.477)\end{array}$ & $\begin{array}{l}-568.049 \\
(1,196.886)\end{array}$ & $\begin{array}{l}1,000.31 \\
(1,013.343)\end{array}$ & $\begin{array}{l}-258.497 \\
(1,137.166)\end{array}$ & $\begin{array}{l}1,020.78 \\
(888.630)\end{array}$ & $\begin{array}{l}-187.955 \\
(1,129.2)\end{array}$ \\
\hline \multicolumn{9}{|l|}{ (Geography Variables) } \\
\hline Rural (dummy) & $\begin{array}{l}507.811 \\
(1,031.774)\end{array}$ & $\begin{array}{l}-740.81 \\
(1,803.93)\end{array}$ & $\begin{array}{l}316.116 \\
(665.107)\end{array}$ & $\begin{array}{l}-1,169.85 \\
(1,958.1)\end{array}$ & $\begin{array}{l}263.805 \\
(912.613)\end{array}$ & $\begin{array}{l}-1,018.89 \\
(1,901.437)\end{array}$ & $\begin{array}{l}173.075 \\
(810.864)\end{array}$ & $\begin{array}{l}-956.732 \\
(1,900.068)\end{array}$ \\
\hline Kinh ethnicity dummy & $\begin{array}{l}-1,216.08 \\
(993.773)\end{array}$ & $\begin{array}{l}-1,535.90 \\
(1,446.802)\end{array}$ & $\begin{array}{l}-1,108.252 * \\
(657.975)\end{array}$ & $\begin{array}{l}-1,629.62 \\
(1,450.601)\end{array}$ & $\begin{array}{l}-1,261.97 \\
(881.921)\end{array}$ & $\begin{array}{l}-1,789.66 \\
(1,456.219)\end{array}$ & $\begin{array}{l}-1,101.98 \\
(781.095)\end{array}$ & $\begin{array}{l}-1,682.25 \\
(1,445.133)\end{array}$ \\
\hline Ha Tay province dummy & $\begin{array}{l}1,807.406^{* *} \\
(717.189)\end{array}$ & $\begin{array}{l}858.923 \\
(801.606)\end{array}$ & $\begin{array}{l}2,125.490 * * * \\
(467.675)\end{array}$ & $\begin{array}{l}740.21 \\
(798.650)\end{array}$ & $\begin{array}{l}1,874.435 * * * \\
(642.962)\end{array}$ & $\begin{array}{l}657.197 \\
(851.206)\end{array}$ & $\begin{array}{l}1,669.675^{* * * *} \\
(564.744)\end{array}$ & $\begin{array}{l}653.231 \\
(812.574)\end{array}$ \\
\hline Lao Cai province dummy & $\begin{array}{l}-234.572 \\
(971.892)\end{array}$ & $\begin{array}{l}-421.156 \\
(1,461.184)\end{array}$ & $\begin{array}{l}362.45 \\
(636.785)\end{array}$ & $\begin{array}{l}-747.257 \\
(1,455.954)\end{array}$ & $\begin{array}{l}-98.011 \\
(853.385)\end{array}$ & $\begin{array}{l}-637.557 \\
(1,460.371)\end{array}$ & $\begin{array}{l}32.928 \\
(753.262)\end{array}$ & $\begin{array}{l}-566.213 \\
(1,442.174)\end{array}$ \\
\hline Nghe An province dummy & $\begin{array}{l}65.247 \\
(719.914)\end{array}$ & $\begin{array}{l}1,531.03 \\
(1,149.547)\end{array}$ & $\begin{array}{l}688.322 \\
(472.830)\end{array}$ & $\begin{array}{l}1,502.01 \\
(1,027.660)\end{array}$ & $\begin{array}{l}18.625 \\
(651.558)\end{array}$ & $\begin{array}{l}1,294.52 \\
(1,180.015)\end{array}$ & $\begin{array}{l}65.451 \\
(555.191)\end{array}$ & $\begin{array}{l}1,378.65 \\
(1,141.485)\end{array}$ \\
\hline
\end{tabular}

Note: Standard errors (median regression) or robust standard errors (OLS) in brackets.

* significant at $10 \% ; * *$ significant at $5 \% ; * * *$ significant at $1 \%$ 
Table 3. The gap between RIETI-CAP data (long recall) and VHLSS 2006 (short recall) - sum of categorized expenditures on bought/bartered goods (continued)

\begin{tabular}{|c|c|c|c|c|c|c|c|c|}
\hline Specification & $(1)$ & $(2)$ & $(3)$ & (4) & $(5)$ & (6) & $(7)$ & $(8)$ \\
\hline Method & Median reg & OLS & Median reg & OLS & Median reg & OLS & Median reg & OLS \\
\hline \multicolumn{9}{|l|}{ (Conditions of Actual Interviews) } \\
\hline Translator required (dummy) & $\begin{array}{l}-101.383 \\
(1,604.059)\end{array}$ & $\begin{array}{l}-130.726 \\
(1,268.405)\end{array}$ & $\begin{array}{l}142.818 \\
(1,041.536)\end{array}$ & $\begin{array}{l}286.523 \\
(1,359.436)\end{array}$ & $\begin{array}{l}257.457 \\
(1,371.499)\end{array}$ & $\begin{array}{l}252.279 \\
(1,413.709)\end{array}$ & $\begin{array}{l}104.207 \\
(1,254.044)\end{array}$ & $\begin{array}{l}222.328 \\
(1,396.358)\end{array}$ \\
\hline Female respondent & $\begin{array}{l}-252.117 \\
(543.224)\end{array}$ & $\begin{array}{l}-467.868 \\
(961.072)\end{array}$ & & & & & & \\
\hline Respondent is head's son (dummy) & & & $\begin{array}{l}-1,156.97 \\
(1,170.683)\end{array}$ & $\begin{array}{l}-2,762.90 \\
(2,274.276)\end{array}$ & $\begin{array}{l}-474.081 \\
(1,358.108)\end{array}$ & $\begin{array}{l}-2,162.13 \\
(1,460.043)\end{array}$ & $\begin{array}{l}-1,156.96 \\
(1,105.063)\end{array}$ & $\begin{array}{l}-2,801.920 * * \\
(1,344.340)\end{array}$ \\
\hline Respondent is head's daughter (dummy) & & & $\begin{array}{l}-1,402.19 \\
(1,732.054)\end{array}$ & $\begin{array}{l}77.731 \\
(3,141.542)\end{array}$ & $\begin{array}{l}-577.097 \\
(1,712.922)\end{array}$ & $\begin{array}{l}716.613 \\
(2,661.339)\end{array}$ & $\begin{array}{l}-1,213.11 \\
(1,921.293)\end{array}$ & $\begin{array}{l}82.406 \\
(2,559.607)\end{array}$ \\
\hline Respondent is female head or wife (dummy) & & & $\begin{array}{l}1,537.44 \\
(1,128.841)\end{array}$ & $\begin{array}{l}2,416.41 \\
(2,153.941)\end{array}$ & $\begin{array}{l}-84.069 \\
(870.469)\end{array}$ & $\begin{array}{l}-225.971 \\
(1,104.471)\end{array}$ & $\begin{array}{l}-171.877 \\
(421.953)\end{array}$ & $\begin{array}{l}-569.896 \\
(990.953)\end{array}$ \\
\hline Respondent's age*Respondent is female head or wife (dummy) & & & $\begin{array}{l}-40.260 * * \\
(17.505)\end{array}$ & $\begin{array}{l}-61.716^{*} \\
(31.483)\end{array}$ & & & & \\
\hline Respondent's age*Respondent is male head or husband (dummy) & & & $\begin{array}{l}-6.299 \\
(14.240)\end{array}$ & $\begin{array}{l}-0.8 \\
(39.937)\end{array}$ & & & & \\
\hline $\begin{array}{l}\text { Respondent is female head or wife and has graduated } \\
\text { from primary school (dummy) } \\
\text { Respondent is male head or husband and has graduated } \\
\text { from primary school (dummy) }\end{array}$ & & & & & $\begin{array}{l}334.405 \\
(799.398) \\
608.136 \\
(714.515)\end{array}$ & $\begin{array}{l}290.599 \\
(1,030.319) \\
762.654 \\
(1,140.240)\end{array}$ & & \\
\hline Constant & $\begin{array}{l}2,635.40 \\
(1,864.515)\end{array}$ & $\begin{array}{l}6,222.371 * * * \\
(2,372.998)\end{array}$ & $\begin{array}{l}3,896.720 * * * \\
(1,395.446)\end{array}$ & $\begin{array}{l}7,465.727 * * \\
(3,516.460)\end{array}$ & $\begin{array}{l}2,782.91 \\
(1,700.485)\end{array}$ & $\begin{array}{l}6,543.246^{* * *} \\
(2,557.651)\end{array}$ & $\begin{array}{l}2,537.125^{*} \\
(1,503.655)\end{array}$ & $\begin{array}{l}6,407.495 * * \\
(2,480.965)\end{array}$ \\
\hline Observations & 396 & 396 & 396 & 396 & 396 & 396 & 396 & 396 \\
\hline F test: coeff. of all var $=0$ & 2.69 & 1.21 & 6.53 & 1.23 & 2.98 & 1.14 & 3.86 & 1.19 \\
\hline Prob $>$ F & {$[0.001]$} & {$[0.27]$} & {$[0.000]$} & {$[0.23]$} & {$[0.000]$} & {$[0.31]$} & {$[0.000]$} & {$[0.27]$} \\
\hline $\begin{array}{l}\text { F test: zero coeff of var other than income, number } \\
\text { of household members and province dummies }\end{array}$ & 0.59 & 0.61 & 1.82 & 1.04 & 0.62 & 0.76 & 0.82 & 0.82 \\
\hline Prob $>$ F & {$[0.81]$} & {$[0.78]$} & {$[0.04]$} & {$[0.42]$} & {$[0.84]$} & {$[0.7]$} & {$[0.63]$} & {$[0.63]$} \\
\hline R-squared & & 0.05 & & 0.06 & & 0.06 & & 0.06 \\
\hline
\end{tabular}

Note: Standard errors (median regression) or robust standard errors (OLS) in brackets.

* significant at $10 \% ; * *$ significant at $5 \% ; * * *$ significant at $1 \%$ 
Table 4. The gap between RIETI-CAP data (long recall) and VHLSS 2006 (short recall) - sum of categorized consumption of self-generated goods

\begin{tabular}{|c|c|c|c|c|c|c|c|c|}
\hline $\begin{array}{l}\text { Specification } \\
\text { Method }\end{array}$ & $\begin{array}{c}(1) \\
\text { Median reg }\end{array}$ & $\begin{array}{l}(2) \\
\text { OLS }\end{array}$ & $\begin{array}{c}(3) \\
\text { Median reg }\end{array}$ & $\begin{array}{l}(4) \\
\text { OLS }\end{array}$ & $\begin{array}{c}(5) \\
\text { Median reg } \\
\end{array}$ & $\begin{array}{l}(6) \\
\text { OLS }\end{array}$ & $\begin{array}{c}(7) \\
\text { Median reg }\end{array}$ & $\begin{array}{l}(8) \\
\text { OLS }\end{array}$ \\
\hline \multicolumn{9}{|l|}{ (Household's and Head's Characteristics) } \\
\hline Asset in 2007 & $\begin{array}{l}-8.074 * * * \\
(2.308)\end{array}$ & $\begin{array}{l}-6.874 * * \\
(3.418)\end{array}$ & $\begin{array}{l}-8.378^{* * * *} \\
(1.859)\end{array}$ & $\begin{array}{l}-6.609^{*} \\
(3.580)\end{array}$ & $\begin{array}{l}-8.745^{* * *} \\
(1.331)\end{array}$ & $\begin{array}{l}-6.458^{*} \\
(3.663)\end{array}$ & $\begin{array}{l}-8.348^{* * *} \\
(1.316)\end{array}$ & $\begin{array}{l}-6.003 \\
(3.939)\end{array}$ \\
\hline Total income in 2007 & $\begin{array}{l}0.295 * * * \\
(0.095)\end{array}$ & $\begin{array}{l}0.425 * * * \\
(0.157)\end{array}$ & $\begin{array}{l}0.335 * * * \\
(0.120)\end{array}$ & $\begin{array}{l}0.436 * * * \\
(0.162)\end{array}$ & $\begin{array}{l}0.330 * * * \\
(0.087)\end{array}$ & $\begin{array}{l}0.422 * * * \\
(0.152)\end{array}$ & $\begin{array}{l}0.282 * * * \\
(0.075)\end{array}$ & $\begin{array}{l}0.427 * * * \\
(0.157)\end{array}$ \\
\hline Increase in income level between 2006 and 2007 & $\begin{array}{l}-0.027 \\
(0.018)\end{array}$ & $\begin{array}{l}-0.054^{*} \\
(0.029)\end{array}$ & $\begin{array}{l}-0.034 \\
(0.025)\end{array}$ & $\begin{array}{l}-0.056^{*} \\
(0.030)\end{array}$ & $\begin{array}{l}-0.034^{*} \\
(0.018)\end{array}$ & $\begin{array}{l}-0.053^{*} \\
(0.028)\end{array}$ & $\begin{array}{l}-0.023 \\
(0.015)\end{array}$ & $\begin{array}{l}-0.052^{*} \\
(0.029)\end{array}$ \\
\hline Number of household members & $\begin{array}{l}67.749 \\
(59.497)\end{array}$ & $\begin{array}{l}72.397 \\
(68.317)\end{array}$ & $\begin{array}{l}69.684 \\
(67.519)\end{array}$ & $\begin{array}{l}88.814 \\
(76.435)\end{array}$ & $\begin{array}{l}108.620 * * \\
(47.262)\end{array}$ & $\begin{array}{l}94.994 \\
(82.426)\end{array}$ & $\begin{array}{l}96.829 * * \\
(47.286)\end{array}$ & $\begin{array}{l}116.609 \\
(86.827)\end{array}$ \\
\hline $\begin{array}{l}\text { The highest education level among household members is at least } \\
\text { secondary school (dummy) }\end{array}$ & & & & & & & $\begin{array}{l}-250.426 \\
(169.574)\end{array}$ & $\begin{array}{l}-747.624 \\
(800.706)\end{array}$ \\
\hline $\begin{array}{l}\text { Head's occupation dummy I (unskilled sales and service } \\
\text { worker) }\end{array}$ & $\begin{array}{l}91.307 \\
(481.473)\end{array}$ & $\begin{array}{l}323.132 \\
(605.040)\end{array}$ & $\begin{array}{l}111.547 \\
(522.300)\end{array}$ & $\begin{array}{l}282.278 \\
(631.049)\end{array}$ & $\begin{array}{l}163.788 \\
(359.627)\end{array}$ & $\begin{array}{l}210.128 \\
(615.458)\end{array}$ & $\begin{array}{l}238.364 \\
(386.652)\end{array}$ & $\begin{array}{l}359.978 \\
(631.519)\end{array}$ \\
\hline $\begin{array}{l}\text { Head's occupation dummy II (unskilled agriculture, forestry, } \\
\text { or aquaculture worker) }\end{array}$ & $\begin{array}{l}279.893 \\
(208.545)\end{array}$ & $\begin{array}{l}315.547 \\
(269.003)\end{array}$ & $\begin{array}{l}261.326 \\
(231.276)\end{array}$ & $\begin{array}{l}244.354 \\
(271.178)\end{array}$ & $\begin{array}{l}172.439 \\
(164.868)\end{array}$ & $\begin{array}{l}254.2 \\
(274.159)\end{array}$ & $\begin{array}{l}266.219 \\
(163.980)\end{array}$ & $\begin{array}{l}210.437 \\
(262.889)\end{array}$ \\
\hline Head’s occupation dummy III (other unskilled worker) & $\begin{array}{l}375.3 \\
(406.947)\end{array}$ & $\begin{array}{l}1,984.01 \\
(1,582.911)\end{array}$ & $\begin{array}{l}398.219 \\
(462.592)\end{array}$ & $\begin{array}{l}1,993.34 \\
(1,628.282)\end{array}$ & $\begin{array}{l}215.666 \\
(330.410)\end{array}$ & $\begin{array}{l}2,022.97 \\
(1,585.694)\end{array}$ & $\begin{array}{l}368.529 \\
(318.150)\end{array}$ & $\begin{array}{l}1,939.90 \\
(1,611.269)\end{array}$ \\
\hline \multicolumn{9}{|l|}{ (Geography Variables) } \\
\hline Rural (dummy) & $\begin{array}{l}-536.375 \\
(432.040)\end{array}$ & $\begin{array}{l}-341.234 \\
(699.084)\end{array}$ & $\begin{array}{l}-597.417 \\
(475.340)\end{array}$ & $\begin{array}{l}-522.176 \\
(671.352)\end{array}$ & $\begin{array}{l}-536.107 \\
(345.087)\end{array}$ & $\begin{array}{l}-639.843 \\
(625.776)\end{array}$ & $\begin{array}{l}-479.543 \\
(345.123)\end{array}$ & $\begin{array}{l}-641.285 \\
(642.000)\end{array}$ \\
\hline Kinh ethnicity dummy & $\begin{array}{l}-954.071 * * * \\
(354.677)\end{array}$ & $\begin{array}{l}-1,714.74 \\
(1,391.276)\end{array}$ & $\begin{array}{l}-1,066.33 * * * \\
(389.987)\end{array}$ & $\begin{array}{l}-1,814.03 \\
(1,430.445)\end{array}$ & $\begin{array}{l}-858.840 * * * \\
(277.086)\end{array}$ & $\begin{array}{l}-1,694.09 \\
(1,300.883)\end{array}$ & $\begin{array}{l}-892.444 * * * \\
(280.421)\end{array}$ & $\begin{array}{l}-1,775.27 \\
(1,408.762)\end{array}$ \\
\hline Ha Tay province dummy & $\begin{array}{l}170.782 \\
(246.688)\end{array}$ & $\begin{array}{l}102.605 \\
(315.996)\end{array}$ & $\begin{array}{l}105.905 \\
(271.115)\end{array}$ & $\begin{array}{l}85.294 \\
(321.950)\end{array}$ & $\begin{array}{l}139.417 \\
(200.530)\end{array}$ & $\begin{array}{l}201.521 \\
(371.832)\end{array}$ & $\begin{array}{l}146.038 \\
(195.724)\end{array}$ & $\begin{array}{l}250.389 \\
(355.374)\end{array}$ \\
\hline Lao Cai province dummy & $\begin{array}{l}-730.589 * * \\
(347.133)\end{array}$ & $\begin{array}{l}462.616 \\
(1,169.414)\end{array}$ & $\begin{array}{l}-828.274 * * \\
(381.192)\end{array}$ & $\begin{array}{l}418.365 \\
(1,165.075)\end{array}$ & $\begin{array}{l}-666.989 * * \\
(267.206)\end{array}$ & $\begin{array}{l}404.532 \\
(1,181.042)\end{array}$ & $\begin{array}{l}-828.390 * * * \\
(276.688)\end{array}$ & $\begin{array}{l}350.413 \\
(1,161.415)\end{array}$ \\
\hline Nghe An province dummy & $\begin{array}{l}-275.044 \\
(246.866)\end{array}$ & $\begin{array}{l}-239.933 \\
(323.153)\end{array}$ & $\begin{array}{l}-343.21 \\
(278.217)\end{array}$ & $\begin{array}{l}-289.754 \\
(341.819)\end{array}$ & $\begin{array}{l}-319.347 \\
(202.974)\end{array}$ & $\begin{array}{l}-117.266 \\
(339.147)\end{array}$ & $\begin{array}{l}-295.269 \\
(195.045)\end{array}$ & $\begin{array}{l}-153.935 \\
(308.016)\end{array}$ \\
\hline
\end{tabular}

* significant at $10 \% ; * *$ significant at $5 \% ; * * *$ significant at $1 \%$ 
Table 4. The gap between RIETI-CAP data (long recall) and VHLSS 2006 (short recall) - sum of categorized consumption of self-generated goods (continued)

\begin{tabular}{|c|c|c|c|c|c|c|c|c|}
\hline Specification & $(1)$ & (2) & (3) & (4) & $(5)$ & (6) & $(7)$ & $(8)$ \\
\hline Method & Median reg & OLS & Median reg & OLS & Median reg & OLS & Median reg & OLS \\
\hline \multicolumn{9}{|l|}{ (Conditions of Actual Interviews) } \\
\hline Translator required (dummy) & $\begin{array}{l}-995.340^{*} \\
(531.552)\end{array}$ & $\begin{array}{l}-2,862.24 \\
(1,877.167)\end{array}$ & $\begin{array}{l}-1,063.351^{*} \\
(584.956)\end{array}$ & $\begin{array}{l}-2,896.26 \\
(1,904.125)\end{array}$ & $\begin{array}{l}-908.061 * * \\
(409.880)\end{array}$ & $\begin{array}{l}-3,042.02 \\
(2,134.01)\end{array}$ & $\begin{array}{l}-928.966 * * \\
(403.697)\end{array}$ & $\begin{array}{l}-3,084.52 \\
(2,042.834)\end{array}$ \\
\hline Female respondent & $\begin{array}{l}-219.896 \\
(186.526)\end{array}$ & $\begin{array}{l}-576.866 \\
(362.974)\end{array}$ & & & & & & \\
\hline Respondent is head's son (dummy) & & & $\begin{array}{l}746.351 \\
(671.914)\end{array}$ & $\begin{array}{l}-323.369 \\
(725.264)\end{array}$ & $\begin{array}{l}676.971 \\
(430.404)\end{array}$ & $\begin{array}{l}-994.484 \\
(1,295.33)\end{array}$ & $\begin{array}{l}759.639 * \\
(403.373)\end{array}$ & $\begin{array}{l}-376.635 \\
(612.754)\end{array}$ \\
\hline Respondent is head's daughter (dummy) & & & $\begin{array}{l}-1,110.37 \\
(1,010.750)\end{array}$ & $\begin{array}{c}-2,370.97 * * \\
(1,103.568)\end{array}$ & $\begin{array}{l}-1,061.41 \\
(692.831)\end{array}$ & $\begin{array}{l}-3,038.37^{*} \\
(1,712.669 \\
)\end{array}$ & $\begin{array}{l}-838.259 \\
(674.031)\end{array}$ & $\begin{array}{l}-2,423.34 * * \\
(1,036.570)\end{array}$ \\
\hline Respondent is female head or wife (dummy) & & & $\begin{array}{l}208.52 \\
(641.248)\end{array}$ & $\begin{array}{l}-682.701 \\
(925.737)\end{array}$ & $\begin{array}{l}-47.668 \\
(270.364)\end{array}$ & $\begin{array}{l}-1,030.09 \\
(1,092.678 \\
)\end{array}$ & $\begin{array}{l}-316.713 * * \\
(148.466)\end{array}$ & $\begin{array}{l}-613.876 \\
(406.030)\end{array}$ \\
\hline Respondent's age*Respondent is female head or wife (dummy) & & & $\begin{array}{l}-6.161 \\
(10.042)\end{array}$ & $\begin{array}{l}6.029 \\
(12.959)\end{array}$ & & & & \\
\hline Respondent's age*Respondent is male head or husband (dummy) & & & $\begin{array}{l}1.648 \\
(8.110)\end{array}$ & $\begin{array}{l}3.895 \\
(10.306)\end{array}$ & & & & \\
\hline $\begin{array}{l}\text { Respondent is female head or wife and has graduated } \\
\text { from primary school (dummy) } \\
\text { Respondent is male head or husband and has graduated } \\
\text { from primary school (dummy) }\end{array}$ & & & & & $\begin{array}{l}-136.746 \\
(250.848) \\
93.738 \\
(226.889)\end{array}$ & $\begin{array}{l}-80.052 \\
(447.121) \\
-677.91 \\
(1,214.859\end{array}$ & & \\
\hline Constant & $\begin{array}{l}2,371.374 * * \\
* \\
(665.750)\end{array}$ & $\begin{array}{l}3,084.047 * \\
* \\
(1,443.218)\end{array}$ & $\begin{array}{l}2,522.981 * * \\
* \\
(824.381)\end{array}$ & $\begin{array}{l}3,185.502 * \\
* \\
(1,594.082)\end{array}$ & $\begin{array}{l}2,128.331 * * \\
* \\
(542.151)\end{array}$ & $\begin{array}{l}3,774.708 * \\
(2,004.376\end{array}$ & $\begin{array}{l}2,364.623 * * \\
* \\
(538.770)\end{array}$ & $\begin{array}{l}3,836.697 * \\
* \\
(1,835.424)\end{array}$ \\
\hline Observations & 362 & 362 & 362 & 362 & 362 & 362 & 362 & 362 \\
\hline F test: coeff. of all var $=0$ & 4.91 & 2.58 & 4.9 & 2.18 & 9.06 & 2.16 & 9.73 & 2.22 \\
\hline Prob $>$ F & {$[0.000]$} & [0.001] & [0.000] & [0.004] & {$[0.000]$} & [0.004] & [0.000] & [0.004] \\
\hline F test: zero coeff of var other than asset, income and province dummies & 2.59 & 1.54 & 1.96 & 1.44 & 3.14 & 1.51 & 3.75 & 1.48 \\
\hline Prob $>$ F & {$[0.0068]$} & {$[0.13]$} & {$[0.02]$} & {$[0.14]$} & {$[0.000]$} & {$[0.11]$} & {$[0.000]$} & {$[0.13]$} \\
\hline R-squared & & 0.05 & & 0.05 & & 0.05 & & 0.06 \\
\hline
\end{tabular}

Note: Standard errors (median regression) or robust standard errors (OLS) in brackets.

* significant at $10 \% ; * *$ significant at $5 \% ; * * *$ significant at $1 \%$. 
Table 5. Test of mean reverting measurement errors

\begin{tabular}{|c|c|c|c|c|}
\hline Specification & $(1)^{+}$ & $(2)^{+}$ & $(3)^{++}$ & $(4)^{++}$ \\
\hline \multirow[t]{2}{*}{ Dependent variable } & (bought & (self-generated) & (bought & (self-generated) \\
\hline & /bartered) & & /bartered) & \\
\hline \multicolumn{5}{|l|}{ Independent variable } \\
\hline \multicolumn{5}{|l|}{ [Without province fixed effects] } \\
\hline Short recall $(\lambda-1)$ & 0.097 & -0.128 & -0.164 & 0.076 \\
\hline (Unadjusted standard error) & $(0.078)$ & $(0.111)$ & $(0.082)^{* *}$ & $(0.120)$ \\
\hline (Robust standard error) & $(0.146)$ & $(0.105)$ & $(0.169)$ & $(0.175)$ \\
\hline R-squared & 0.004 & 0.004 & 0.01 & 0.01 \\
\hline \multicolumn{5}{|l|}{ [With province fixed effects] } \\
\hline Short recall $(\lambda-1)$ & 0.098 & -0.176 & -0.153 & -0.037 \\
\hline (Unadjusted standard error) & $(0.079)$ & $(0.122)$ & $(0.083)^{*}$ & $(0.132)$ \\
\hline (Robust standard error) & $(0.150)$ & $(0.113)$ & $(0.170)$ & $(0.121)$ \\
\hline R-squared & 0.01 & 0.03 & 0.02 & 0.01 \\
\hline \multicolumn{5}{|l|}{ [With district fixed effects] } \\
\hline Short recall $(\lambda-1)$ & 0.026 & -0.160 & -0.260 & -0.072 \\
\hline (Unadjusted standard error) & $(0.094)$ & $(0.127)$ & $(0.097)^{* * *}$ & $(0.145)$ \\
\hline (Robust standard error) & $(0.152)$ & $(0.135)$ & $(0.170)$ & $(0.142)$ \\
\hline R-squared & 0.17 & 0.21 & 0.21 & 0.12 \\
\hline \multicolumn{5}{|l|}{ [With commune fixed effects] } \\
\hline Short recall $(\lambda-1)$ & -0.061 & -0.039 & -0.300 & 0.021 \\
\hline (Unadjusted standard error) & $(0.111)$ & $(0.150)$ & $(0.115)^{* * *}$ & $(0.196)$ \\
\hline (Robust standard error) & $(0.155)$ & $(0.191)$ & $(0.161)^{*}$ & $(0.286)$ \\
\hline R-squared & 0.5 & 0.6 & 0.51 & 0.42 \\
\hline Observations & 398 & 366 & 398 & 366 \\
\hline
\end{tabular}

Note: $*$ significant at $10 \% ; * *$ significant at $5 \% ; * * *$ significant at $1 \%$.

+ the gap between the long-recall total expenditure (RIETI-CAP) and short-recall aggregate expenditures (VHLSS 2006).

${ }^{++}$the gap between the long-recall sum of categorized expenditures (RIETI-CAP) and short-recall aggregate expenditures (VHLSS 2006). 
Table 6. Tests of the mean reverting measurement errors:

Sum of categorized expenditures on bought/bartered goods (controlling for income and household size)

\begin{tabular}{lll}
\hline Specification & $(5)$ & $(6)$ \\
\hline Fixed effects & none & $\begin{array}{l}\text { province fixed } \\
\text { effects }\end{array}$ \\
\hline Independent variable & & \\
\hline Short recall $(\lambda-1)$ & -0.135 & -0.122 \\
(Unadjusted standard error) & $(0.087)$ & $(0.088)$ \\
(Robust standard error) & $(0.182)$ & $(0.183)$ \\
& & \\
Income in 2007 & -0.001 & -0.001 \\
(Unadjusted standard error) & $(0.004)$ & $(0.004)$ \\
(Robust standard error) & $(0.003)$ & $(0.003)$ \\
Number of household members & -363.17 & -385.60 \\
(Unadjusted standard error) & $(254.04)$ & $(256.20)$ \\
(Robust standard error) & $(250.30)$ & $(268.03)$ \\
R-squared & & \\
Observations & 0.02 & 0.02 \\
\hline
\end{tabular}

Note 1: Standard errors in parentheses.

Note 2: The dependent variable is the gap between the long-recall sum of categorized expenditures (RIETI-CAP) and short-recall aggregate expenditures (VHLSS 2006). 
Figure 1: Cumulative distribution functions (Total expenditure)

2(a) Bought/bartered goods

Total expenditure: Bought/bartered goods

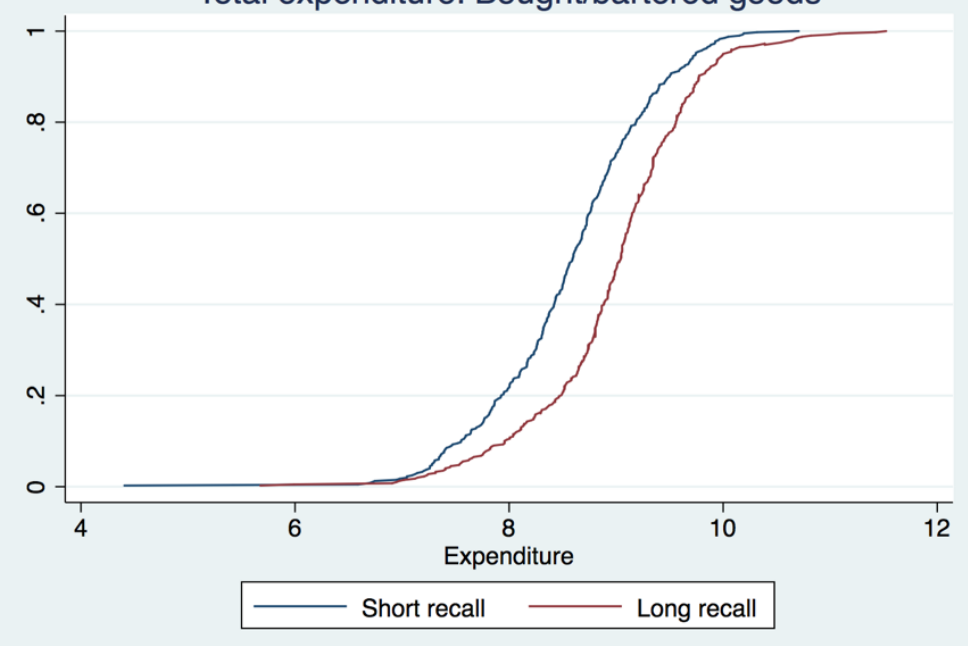

2(b) Self-generated goods

Total expenditure: Self-generated goods

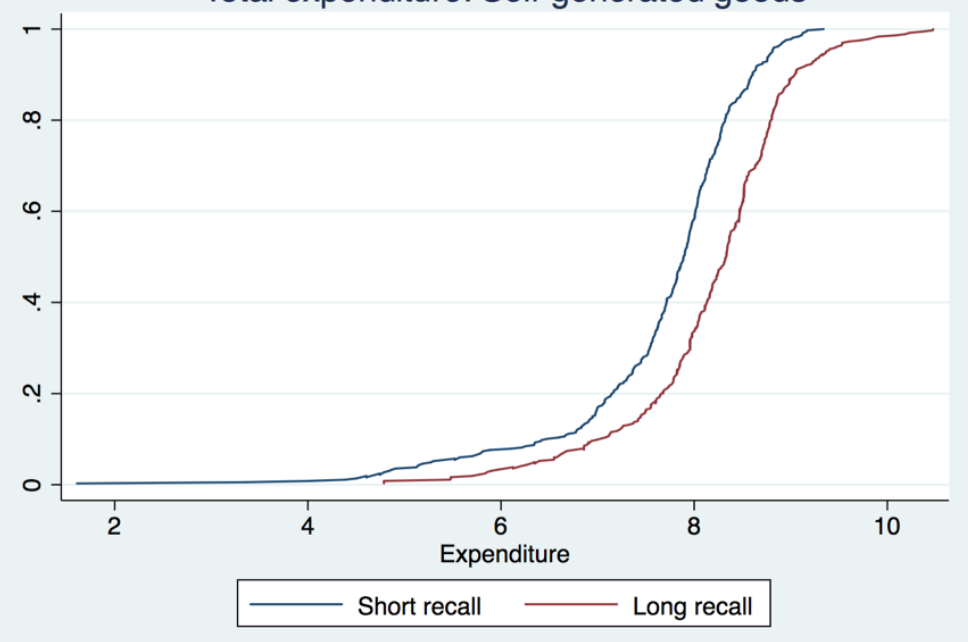

Short recall: Log of aggregate expenditures in VHLSS 2006

Long recall: $\log$ of total expenditure in RIETI-CAP 
Figure 2: Cumulative distribution functions (Sum of categorized expenditures)

\section{3(a) Bought/bartered goods}

Categorical expenditure: Bought/bartered goods

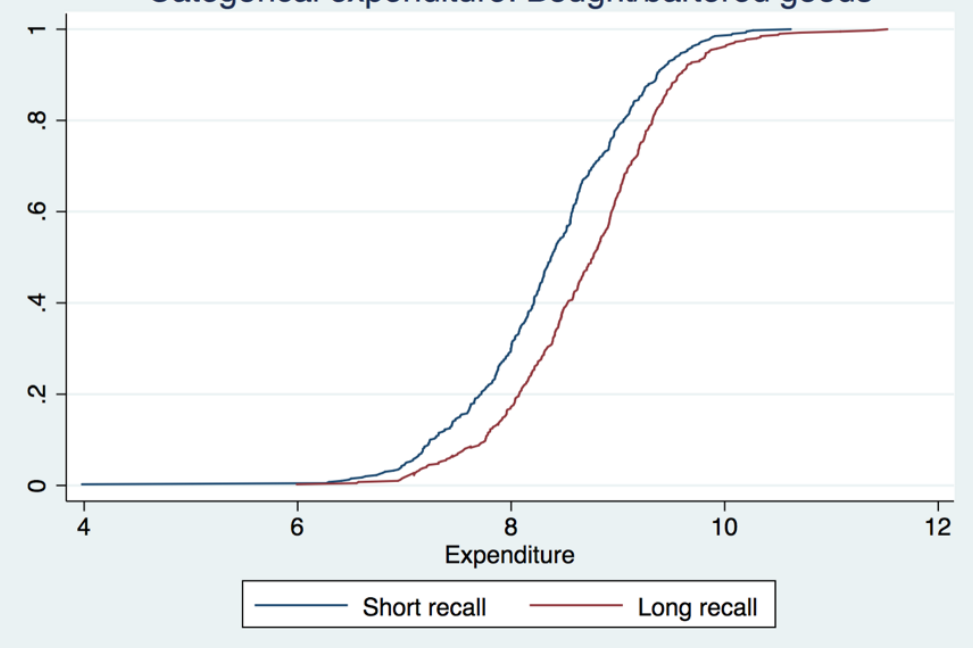

\section{3(b) Self-generated goods}

Categorical expenditure: Self-generated goods

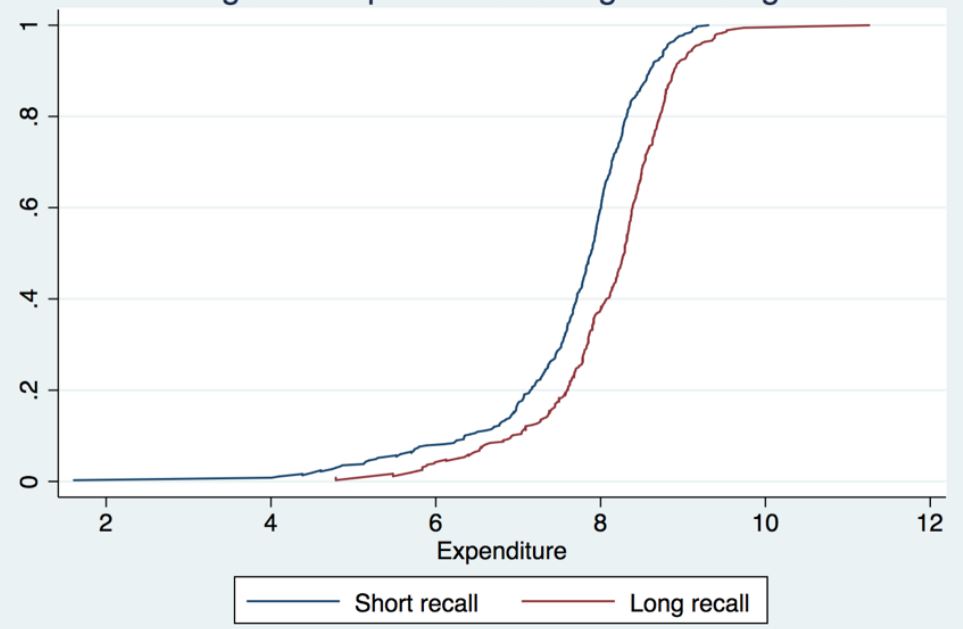

Short recall: Log of aggregate expenditures in VHLSS 2006

Long recall: Log of sum of categorized expenditures in RIETI-CAP 
Figure 3: Cumulative distribution functions (RIETI-CAP data on consumption in 2007)

\section{4(a) Bought/bartered goods}

Bought/bartered goods

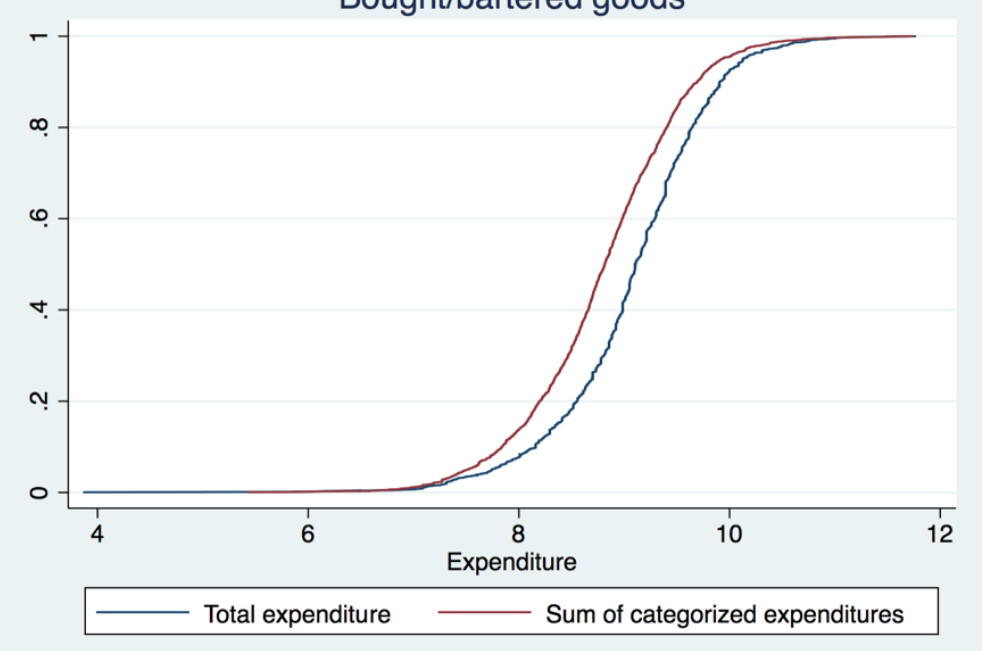

4(b) Self-generated goods

Self-generated goods

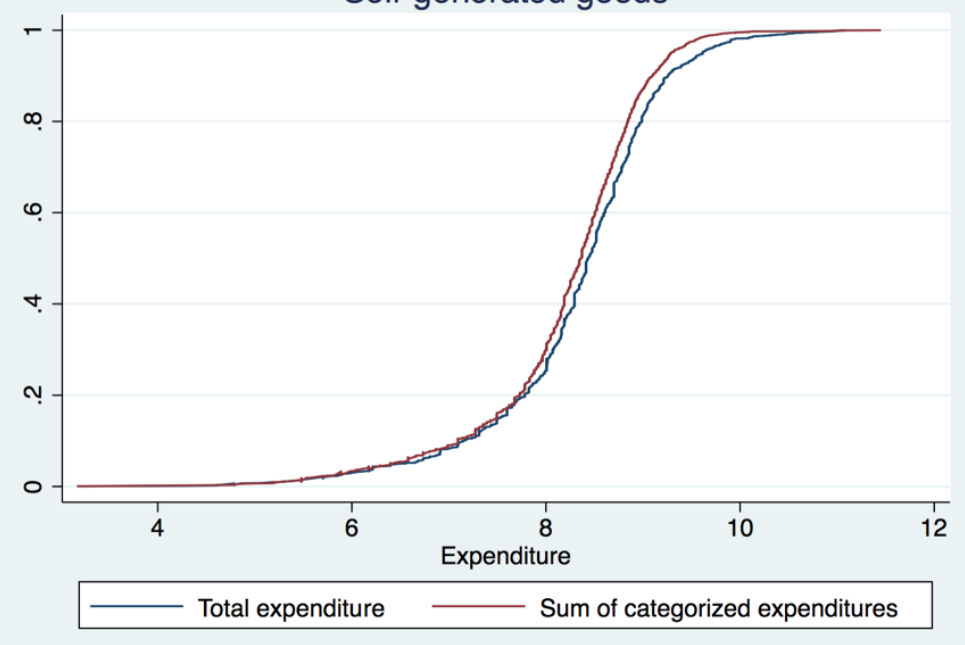

Total Expenditure: Log of total expenditure in RIETI-CAP

Sum of categorized expenditure: Log of the sum in RIETI-CAP 
Appendix A. Surveyed Provinces

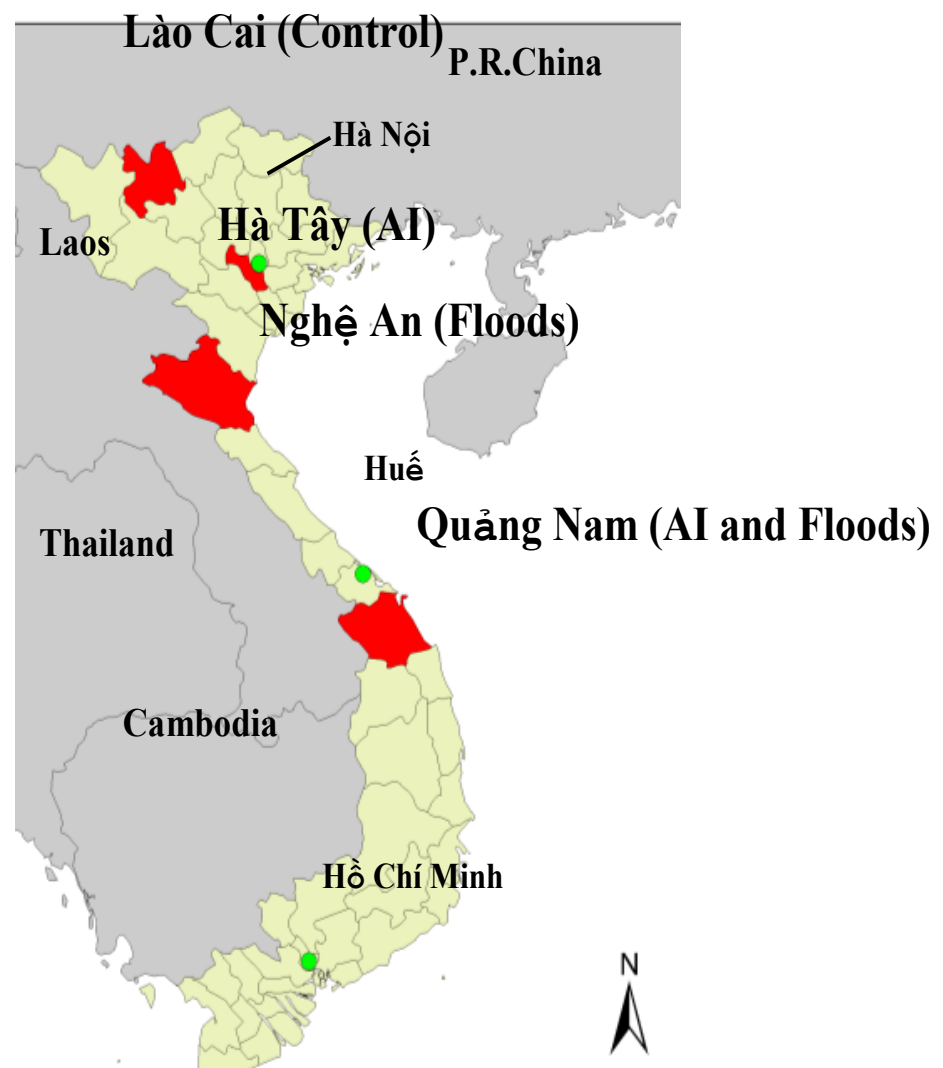




\section{Appendix B. RIETI-CAP Survey Expenditure Module}

Section 15 EXPENDITURE

Section 15A Expenditure by Category EXCEPT during holidays

\begin{tabular}{|c|c|c|c|c|}
\hline \multirow{2}{*}{ Code } & & \multicolumn{2}{|c|}{ BOUGHT OR BARTERED } & SELF-GENERATED OR GIVEN \\
\hline & $\begin{array}{l}\text { 1 Apart from holidays, indicate which of the following items } \\
\text { has your household consumed in the last } 12 \text { months? } \\
\text { ASK QUESTION } 1 \text { FOR ALL ITEMS BEFORE STARTING } \\
\text { QUESTIONS 2-4 } \\
\text { MARK X IF YES }\end{array}$ & $\begin{array}{l}2 \\
\text { How many times a month on } \\
\text { average did your household buy } \\
\text { or barter? } \\
\text { (times) }\end{array}$ & $\begin{array}{l}\text { 3 } \\
\text { The average value each time your } \\
\text { household bought or bartered } \\
\text { (thousand VND) }\end{array}$ & $\begin{array}{l}4 \\
\text { Value of self-generated or given goods consumed or } \\
\text { received per month } \\
\text { (thousand VND) }\end{array}$ \\
\hline 1 & Rice & p15ac21 & p15ac31 & p15ac41 \\
\hline 2 & Meat & $\mathrm{p} 15 \mathrm{ac} 22$ & p15ac32 & p15ac42 \\
\hline 3 & Fish and shrimps & p15ac23 & p15ac33 & p15ac43 \\
\hline 4 & - & p15ac24 & p15ac34 & $\mathrm{p} 15 \mathrm{ac} 44$ \\
\hline 5 & Sugar, molasses, cake, candy & p15ac25 & p15ac35 & p15ac45 \\
\hline 6 & Alcohol and beer & p15ac26 & p15ac36 & p15ac46 \\
\hline 7 & Vegetable & p15ac27 & p15ac37 & p15ac47 \\
\hline 8 & Fruits & p15ac28 & p15ac38 & $\mathrm{p} 15 \mathrm{ac} 48$ \\
\hline 9 & Eating out & p15ac29 & p15ac39 & p15ac49 \\
\hline 10 & Clothing, hat, shoes & p15ac210 & p15ac310 & p15ac410 \\
\hline 11 & Transportation, communication & p15ac211 & Per month & p15ac411 \\
\hline 12 & Culture, sports and recreation & p15ac212 & p15ac312 & p15ac412 \\
\hline
\end{tabular}

Section 15B Total Expenditure

\begin{tabular}{|l|l|c|l|}
\hline Code & & $\begin{array}{l}\text { l. } \\
\text { The total value [Please confirm } \\
\text { that the amount is the total for } \\
\text { the last 12 months } \\
\text { (Thousand VND) }\end{array}$ & $\begin{array}{l}\text { 2. } \\
\text { Compared to last year, was the } \\
\text { amount increased/decreased? Please } \\
\text { pick one number from the answer } \\
\text { code }\end{array}$ \\
\hline 1 & $\begin{array}{l}\text { Items bought or bartered in the last } \\
12 \text { months EXCEPT during holidays }\end{array}$ & p15bc11 & p15bc21 \\
\hline 2 & $\begin{array}{l}\text { Items self-generated or given in the last } \\
12 \text { months EXCEPT during holidays }\end{array}$ & p15bc12 & p15bc22 \\
\hline 3 & $\begin{array}{l}\text { Items bought or bartered in the last } \\
12 \text { months DURING holidays }\end{array}$ & p15bc13 & p15bc23 \\
\hline 4 & $\begin{array}{l}\text { Items self-generated or given in the last } \\
12 \text { months DURING holidays }\end{array}$ & & \\
\hline
\end{tabular}

\begin{tabular}{|l|l|}
\hline CODE for Q2 & \\
\hline$>=50 \%$ decrease & 1 \\
\hline $30-50 \%$ decrease & 2 \\
\hline $10-30 \%$ decrease & 3 \\
\hline $0-10 \%$ decrease & 4 \\
\hline No change & 5 \\
\hline $0-10 \%$ increase & 6 \\
\hline $10-30 \%$ increase & 7 \\
\hline $30-50 \%$ increase & 8 \\
\hline$>=50 \%$ increase & 9 \\
\hline
\end{tabular}

